\title{
TAHÂVÎ BAĞLAMINDA İKİ FARKLI HANEFÎLİK OKUMASI (EKMELÜDDÎN EL-BÂBERTÎ VE İBN EBİ'L-İZZ ÖRNEĞİ)
}

\author{
Mustafa Aykaç \\ Dr. Öğr. Üyesi Üyesi, Kastamonu Üniversitesi, İlahiyat Fakültesi, Kelâm ve Mezhepler Tarihi Anabilim Dalı \\ Asst. Prof., Kastamonu University, Faculty of Theology, Department of Kalam and History of Islamic Sects. \\ Kastamonu, Turkey \\ maykac@kastamonu.edu.tr \\ orcid.org/0000-0003-3126-1070 \\ Doi: $10.14395 /$ hititilahiyat.443578
}

Öz

Hem Müslümanın günlük hayatında karşılaşabileceği sorunlara makul ve pratik fıkhî çözümler getirmesi, hem de kucaklayıcı itikâdî görüşleri ile Ebû Hanîfe (ö.150/M.767), sadece mevâlinin değil tüm Müslümanlar katında önemli bir âlim olmuştur. Onun görüşlerinin Mısır bölgesinde takipçisi ve belirgin ilk temsilcisi İmam Tahâvî’dir (ö.321/M.933). Bu çalışmada İmam Tahavî üzerinden Mısır'daki Hanefilik algısının izlerini bulmayı hedeflemekteyiz. Bu hedef doğrultusunda çalışmamız, Ekmelüddîn el-Bâbertî (ö.786/M.1384) ile İbn Ebi'l-İzz'in (ö.792/M.1390) İmam Tahavî'nin el-Akîdetü't-Tahâviyye veya Beyanü Akîdeti Ehli's-Sünne ve'l-Cemaa isimli eseri üzerine yazdığı şerhlerde ortaya koyulan Hanefilik algısı üzerinden şekillenecektir. Ancak çalışmamızın makale sınırlarını aşmaması için, söz konusu âlimlerin iman görüşleri etrafında bir soruşturma yapılacaktır. Bu hedef doğrultusunda Ekmelüddîn el-Bâbertî ve İbn Ebi'l-İzz'in şerhlerine yansıttığı gelenek tespit edilecek ve Hanefîliğe dair farklı sunumlarının sebebi araştırılacaktır.

Anahtar Kelimeler: Tahâvî, el-Akîdetü't-Tahâviyye, Bâbertî, İbn Ebi'l-İzz, Hanefîlik.

\section{Two Different Reading Of Hanafiyya İn The Context Of Tahâvî (Akmaluddin al-Bâbarti and Ibn Abi'l-Izz Examplification)}

\begin{abstract}
Bringing reasonable and practical solutions to problems that a muslim may face in his daily life and viewing inclusive theologycal views, Abu Hanifa (d.150/767) has been an important scholar for all Muslims not just for Mavali. İmam Tahâvî (d.321/933) has been the first and most representative follower in the region of Egypt. İ this study, we aim to trace the perception of Hanafism in Egypt through İmam Tahâvî's views. In accordance with this target, our work will be based on the perception of Hanafism that was laid by Akmaluddin al-Bâbarti (d.786/1384) and Ibn Abi'l-Izz (d.792/1390) in their books that comments on at-Tahavi's book named as al-Akidatu'tTahaviyya or Bayanu Akidati Ehli's-Sunne va'l-Camaa. However, for our study not to exceed the limits of an article, an investigation will be conducted around the opinions about iman (faith) of the aforementioned scholars. Thus, the traditions that Akmaluddin al-Bâbarti and Ibn Abi'l-Izz reflect in their comments, will be identified and the reasons for their presences about Hanafism will be investigated
\end{abstract}

Keywords: Tahâvî, al-Akidatu't-Tahaviyya, Bâbarti, Ibn Abi'I-Izz, Hanafiyya. 


\section{Giriş}

İslâm tarihinde mevâlinin ikinci sınıf Müslüman olarak görülerek, kâfirlerden alınan cizyenin mevaliden de alınması ve Arap unsurunun daha ön planda tutulması, Emevî yönetiminin akılda kalan özelliklerinden biri olmuştur. Ömrünün çoğunu Emevî idaresi altında geçiren Ebû Hanîfe, yaptığı iman tarifi ile kısa sürede mevâlinin gönlünde yer edinmiştir. İmanı kalbin tasdiki ve dilin ikrarı olarak tarif eden Ebu Hanîfe, o zamanlar ikinci sınıf Müslüman olarak kabul edilen mevalinin ${ }^{1}$, kalbinde tasdik, dilinde de ikrar bulunması sebebiyle, hakiki ve birinci sınıf mü'min olduğunu söyleyerek eşitlikçi iman anlayışını ortaya koymuştur. ${ }^{2}$ Bütün Müslümanları içine alan iman tarifi gibi diğer itikâdî görüşleri ile dikkatleri üzerine çeken Ebû Hanîfe, Müslümanın günlük hayatında karşılaşabileceği sorunlara makul ve pratik fikhî çözümler getirmesiyle de, sadece mevâli için değil tüm Müslümanlar için önemli bir âlim olmuştur. Birçok İslâm beldesinden talebeler gelerek ondan ders almış, memleketlerine dönünce de onun fikirlerini yaymıştır. Böylece Ebû Hanîfe' nin görüşleri, kısa zamanda Müslümanlar arasında, özellikle de mevâlinin yoğun olarak yaşadığı Irak, Horasan ve Mâverâünnehir taraflarında kabul görmüş, hiç gitmediği topraklarda insanlar birer Ebû Hanîfe takipçisi oluvermişlerdir. Dahası, Ebû Hanîfe takipçiliği ve sevgisi o kadar artmış ki, peygamberimizin ağzından bile onu öven sözler rivayet edilir olmuştur. ${ }^{3}$

Ebû Hanîfe'nin gerek itikadî gerekse fıkhî görüşleri, yaşadığı Irak bölgesinin doğusunda geniş kabul görse de, batısı ve güneyindeki yayılması sınırlı kalmıştır. Onun fikirlerinin Mısır'daki önemli ilk temsilcilerinden biri Ebû Ca'fer et-Tahavî olmuştur. Tahavî, 239/853 yılında Mısır'ın güneyinde Nil nehrinin batı yakasındaki Eşmûnîn'e bağlı Tahâ köyünde saygın bir ailenin çocuğu olarak dünyaya gelmiştir. İlk eğitimini babası, dayısı ve Ebû Zekeriyyâ İbn Amrus'tan almıştır. Sonraki hocaları arasında 260/874 yılında Mısır'a kadı olarak tayin edilen Ebû Ca'fer Ahmed b. Ebû İmrân el-Bağdâdî,

1 Sönmez Kutlu, Türklerin İslamlaşma sürecinde Mürcie ve Tesirleri, 3. Baskı (Ankara: Türkiye Diyanet Vakfi Yay, 2010), 49.

2 Osman Aydınlı, "Mezheplerin Olușum Sürecinde Mevâlı̂’nin Rolü”, Gazi Üniversitesi Çorum İlahiyat Fakültesi Dergisi, 2/3: 14.

3 Bu rivayetlerin bazıları için bk. Taşköprîzade Ahmed b. Mustafa, Miftâhu's-saâde ve misbâhu's-siyâde fi mevzûati'l-ulûm, (Beyrut, Dâru'l-Kütübi'l-İlmiyye, 1985) 3: 175. (Taşköprîzade eserinde özetle şunları zikretmektedir: Ebû Hureyre'den mervî bir rivayette peygamberimiz, "Ümmetim içinden Ebû Hanife denilen bir adam gelecektir. O, kıyamet günü ümmetimin ışık kaynağıdır." buyurmuştur. Bir başka rivayette " Nu'man b. Sabit adında Ebû Hanife diye künye verilen biri gelecek ve dini ve sünnetimi tekrar canlandıracaktır." buyurulmaktadır. Başka bir rivayette ise "Ümmetimden her asırda bir önder çıkacaktır. Ebû Hanîfe de zamanının önderidir." buyurulmuştur.) 
İmam Ebû Yusuf ve İmam Muhammed'in önde gelen öğrencilerinin yer alması, kendisine, onların görüşlerini, mezhebin inceliklerini ve bu görüşlere ilişkin rivayet farklılıklarını sağlam kaynaklardan öğrenme imkânı vermiştir. Böylece Ebû Hanîfe' nin ilim dünyasını önemli kaynaklardan öğrenme imkânı bulmuş, yirmi bir veya yirmi iki yaşında iken Şâfiî mezhebinden Hanefî mezhebine geçmiştir. ${ }^{4}$

Mesleği kadı yardımcılığı, nâiblik ve kâtiplik olan Tahâvî, 311/924'ten vefat ettiği 321/933 yılına kadar eğitim ve telifle uğraşmıştır. Meşhur hadis âlimleri Müslim, İbn Mâce, Ebû Dâvud ve Nesâî ile ortak hadis aldığı şeyhleri vardır. ${ }^{5}$ Tahâvî'nin eserleri öncelikli olarak hadis ve fikıh ilmine dairdir. Kelâm ilmine dair sadece el-Akîdetü't-Tahâviyye veya Beyanü Akîdeti Ehli's-Sünne ve'l-Cemaa isimli akâid kitabını yazmıştır. Onun Hanefî mezhebini tercihinin, Mısır'a dış tesirlerle taşınan Hanefîliğin iyice yerleşmesi ve yayılmasına sebep olduğu söylenebilir. Fıkıh alanlarında yazdığı eserlerle Hanefîliğin oluşumuna ve yayılmasına, farklı türlerde literatürün ortaya çıkışına öncülük etmiştir. Hanefî imamlarının fikirlerine dair ilk özet eser olan el-Muhtasar'1, İmam Muhammed'in el-Câmi'u's-sağ̀ir ve el-Câmi'u'l-kebîr'ine yazdığı şerhleri, mezhep görüşlerinin hadisle temellendirilmesine yönelik hacimli kitapları ve mahkeme sicili düzenleme usulünü konu edinen şurût ilmine dair eserleriyle, Hanefî fıkıh literatürüne önemli katkılar sağlamıştır. Özellikle hilâfiyata dair yazdığı İhtilâfü'l-ulemâ isimli eseriyle Hanefî imamları yanında diğer mezhep imamlarının ve erken dönem müçtehitlerinin görüşlerini sonraki nesillere aktarmıştır. Hadisçi kimliği ile Hanefî literatür için önemli eserler yazması, hadise karşı muhalefet ile suçlanan Hanefîlere yöneltilen bu tenkitlere ${ }^{6}$ verilmiş en güzel cevaplardan biridir. Bu hadisçi yönü sebebiyle Tahâvî sadece Misır Hanefîleri için değil, tüm Hanefîler için önemli bir âlimdir.

4 Ahmet Karadut, "Ebû Ca'fer et-Tahâvî Hayatı ve Eserleri", Diyanet Dergisi, 19 (1983): 5559; Davut İltaş, "Tahâvî", Türkiye Diyanet Vakfı İslâm Ansiklopedisi (Ankara: TDV Yayınları, 2010) 39: 385.

5 İmam Müslim ile Hârun b. Saîd el-Eylî ve Yunus b. Abdi'l-A'lâ; İbn Mâce ile Hârun b. Saîd el-Eylî; Ebu Davud ile Hârun b. Saîd el-Eylî, Rebi' b. Süleymanel-Cîzî ve Abdulgani b. Rifâa; İmam Nesâi ile Hârun b. Saîd el-Eylî, Rebi' b. Süleyman el-Cîzî ve İbrahim b. Merzûk ortak şeyhleridir. (Ahmet Karadut, age, 53.)

6 Muhammed Zahid el-Kevserî, Fıkhu ehli'l-ırâk ve hadîsuhum, tahk.: Ebu Gudde (Beyrut: 1970) 21.

7 Hanefiliğin Mısır'a giriși, et-Tahâvî öncesi, et-Tahâvî dönemi ve et-Tahâvî sonrası durumu için bk. İhsan Timür, et-Tahâvî'nin Akîde Şerhlerinde İtikadi Farklılaşmalar, (Doktora tezi, Ankara Üniversitesi, 2016), 44-73. 
Tahâvî̀nin günümüze ulaşan tek akâid risalesi "el-Akîdetü't-Tahâviyye" veya "Beyanü Akîdeti Ehli's-Sünne ve'l-Cemaa" isimli eseridir. Bu eser, itikâdî meseleleri Ebû Hanîfe'nin perspektifine uygun bir tarzda ele alarak, Mısır'da Hanefî itikadının en köklü kaynağı olmuştur. Ebu Hanîfe itikadını aktaran ilk kaynaklardan biri olması sebebiyle bu eseri üzerine birçok şerh yazılmıştır. Bunlardan Ekmelüddîn el-Bâbertî ile İbn Ebi'l-İzz'in el-Akîdetü't-Tahâviyye üzerine yazdıkları şerhler aynı dönemlerde yazılan şerhler olmasına karşın, ulaştı̆̆ 1 sonuçlar açısından birbirinden oldukça farklılık arzetmektedir. Bu çalışmamızla, aynı metin üzerinde çalışan bu iki âlimin, birbirinden farklı sonuçlara ulaştı̆̆ını iman meselesi ekseninde ortaya koymaya ve bu farklılığın nedenlerini tespit etmeye çalışacağız.

710/1310'da Bayburt'ta doğduğu, 786/1384'da Mısır'da vefat ettiği düşünülen Bâbertî, hayatını Anadolu, Suriye ve Mısır'da geçirmiştir. İlk eğitimini memleketinde ve Halep'te aldıktan sonra, Kahire'ye giderek, dönemin meşhur âlimlerinden ders alarak eğitimini tamamlamıştır. Fıkıh, hadis, kelâm alanlarında eserler yazan Bâbertî, aralarında Seyyid Şerif el-Cürcânî, Molla Fenârî, Bedreddin Simâvî ve Hacı Paşa gibi birçok talebe yetiştirmiştir. Hanefî mezhebi âlimleri arasında önemli bir yere sahip bulunan ve kaleme aldığı beş ayrı risâlede, Hanefî mezhebinin tercih ve taklit edilmesi gerektiğini savunan Bâbertî, aynı zamanda Mâtürîdî kelamının da önemli âlimlerindendir. ${ }^{8}$ Hanefî mezhebi mensuplarından gelen talep üzerine Ebu Hanîfe hakkında Hanefîleri bilgilendirmek, kimi insanlara göre zayıf gibi görünen yönlerini güçlendirmek, İmam Ebu Hanîfe ve mezhebini taklit etmeyi, diğerlerini taklit etmekten üstün tutup, bu mezhebin taklidini teşvik etmek amaciyla en-Nüketü'z-zarife fì tercihi'l-mezhebi Ebî Hanîfe isimli risaleyi yazmıştır. Ona göre Ebû Hanîfe ve onu takip eden arkadaşları, dinin teorik ve pratik tanımlarını gerçekleştirme bakımından en güçlü ilim adamlarıdır. Rey ve nakil arasında önemli bir denge kuran Ebû Hanîfe ve öğrencileri, dinin aslî ve fer'î konularında ortaya koydukları görüşleri ile bu konularda belirleyici olmuşlardır.

8 Asri Çubukçu, "Ekmelüddîn Bâbertî, Hayatı ve Eserleri”, Ekmelüddîn Bâbertî'yi Keşif Yolunda I. Ekmelüddîn Babertî Sempozyumu, (Erzurum, 2010), 16-18.

9 Bu eser üzerine tahkik ve tercüme çalıșması için bk. Ahmet İnanır, Ekmelüddin Bâbertî’nin "En-Nüketü'z Zarîfetü fî Tercîhi'l-Mezhebi Ebi Hanife" Adlı Risalesinin Tahkik ve Tercümesi, Ekmelüddîn Bâbertî'yi Keşif Yolunda I. Ekmelüddîn Babertî Sempozyumu, (Erzurum, 28-30 Mayıs 2010). Ed. Selçuk Coşkun. (Erzurum: Bayburt Üniversitesi Yayınları, 2014), 303346. 
Bu sebeple fıkıh ve kelâmda kimsenin başaramadığı şeyleri başarmışlardır. ${ }^{10}$ Buna göre bir hanefî olan Bâbertî́nnin aynı zamanda Hanefîliğin güçlü bir savunucusu olduğunu söyleyebiliriz.

İbn Ebi'l-İzz lakabiyla meşhur olan Ebu'l-Hasen Sadrüddîn Ali b. Alâiddîn Ali b. Muhammed ed-Dımeşkî ise 731/1331 yılında muhtemelen Dımaşk'ta doğmuş, 792/1390 yılında yine Dımaşk'ta vefat etmiş hanefî-Ehl-i Hadis bir âlimdir. Hocaları hakkında pek bilgi olmadığından, ilk tahsilini babasından ve yakın çevresindeki âlimlerden yaptığı düşünülmüştür. İlim tahsili için hiç yolculuğa çıkmaması, yaşadığı ortamın ilmi açıdan yetişmesi için müsait olduğu şeklinde düşünülmüştür. İbn Ebi'l-İzz, Hanefî mezhebine bağlı bir muhitte yetişmesine ve kendinin de amelî olarak Hanefî olmasına rağmen Ehl-i Hadis'e ait görüşlere ilgi duymuştur. Zira onun sahabe ve tabiûnun örnekliğini yaptığı dînî hayatı yaşama hususunda Selefî görüşleri benimsemesinde, taklit ve taassuba muhalefetinde Ehl-i Hadis âlimlerinin ${ }^{11}$ büyük tesiri olmuştur. Bâbertî’nin en-Nüketü'z-zarife fi tercihi'l-mezhebi Eb̂̂ Hanîfe isimli eserinde Hanefîliği diğer mezheplerden üstün görerek, tâbi olunması ve taklit edilmesi gereken bir mezhep olarak önermesi üzerine, İbn Ebi'l-İzz "el-İttibâ" isimli risalesini yazarak, Bâbertî'yi eleştirmiş ve taklidin sahabe ve tabiûnun yolu olmadığını anlatmıştır. ${ }^{12}$

Gerek Bâbertî gerekse İbn Ebi'l-İzz Memlûk Devleti zamanında yaşamışlardır. Anadolu'da beylikler döneminde doğan Bâbertî, Memlûk sultanı Barkuk zamanında da vefat etmiştir. İbn Ebi'l-İzz ise, Sultan Nâsır'ın üçüncü kez tahta çıarak yönetimi sahiplendiği bir zamanda doğmuş, Sultan Barkuk'un ikinci kez tahtta olduğu bir dönem içinde de vefat etmiştir. Buna göre Sultan Barkuk'un ilk tahta çıkışında Bâbertî, ikinci kez tahta çıkışında da İbn Ebi'l-İzz vefat etmiştir. İlmî açıdan Bâbertî Anadolu'da doğup Türklerin etki alanlarında ve Hanefî bir eğitim alarak yetişirken, İbn Ebi'l-İzz, amelde Hanefî olsa da İbn Teymiyye' nin fikirlerinin tartışıldığı bir çevrede yetişmiştir. Bâbertî Ana-

10 Ekmeluddîn el-Bâbertî, Serhu Akîdeti Ehli's-Sünne ve'l-Cemâa, Thk. Arif Aytekin (Kuveyt: 1989), 25; Arif Aytekin, "Bâbertî" Türkiye Diyanet Vakfı İslâm Ansiklopedisi (Ankara: TDV Yayınları, 1991) 4: 377-378; Galip Türcan, Bâbertî́nin Kelâm'a Bakışı -Ebû Hanife'nin Etkisi Bağlamında Bir Değerlendirme-, Ekmelüddîn Bâbertî'yi Keşif Yolunda I. Ekmelüddîn Babertî Sempozyumu, (Erzurum, 28-30 Mayıs 2010). Edit.: Selçuk Coşkun. (Erzurum: Bayburt Üniversitesi Yayınları, 2014), 360-365.

11 Örneğin İmâduddîn İbn Kesir'e (774/1373) “Şeyhimiz" demektedir. (Bk. İbn Ebi'lİzz, Şerhu'l-akîdeti't-tahâviyye, thk. Ebû Abdillah Mustafa İbnu'l-Adeviyye, (Baskı yy, 2002/1423) 325.

12 Konu ile ilgili olarak bk. Ahmet İnanır, İbn Ebi'l-İzz'in “İttibâ'” Adlı Risalesi Bağlamında Ebu Hanife ve Hanefi Mezhebi Örneğinde Taklide Dair Görüşleri, Gaziosman Paşa Ün. İlahiyat Fakültesi Dergisi $1 / 2$ (2013): 225-260. 
dolu, Suriye ve Misır bölgelerinde, İbn Ebi'l-İzz de Suriye ve Mısır bölgelerinde olmak üzere, her iki âlim de aynı devlet içinde yaşadığından, yönetim bakımından aynı şartlarda bulundukları tespitini yapabiliriz. Memlûklular, Müslümanların Moğol ve Haçlı saldırılarına uğradığı bir dönemde pek çok âlimi himaye etmiş, eğitim ve öğretime önem vermiş, mevcut medreselerin yanına yeni medreseler yapmış, bu sayede Kahire ve Dımeşk, İslâm dünyasının en önemli iki ilim merkezi haline gelmiştir. Yönetimde Hanefî mezhebinin ağırlığı hissedilse de bu bir mezhebî tahakküme dönüşmemiştir. Medreselerin çoğu Sünnî dört mezhep üzerine öğretim yapan fıkıh medresesi hüviyetinde olup, bazılarında tek, bazılarında ise birkaç mezhebin fikhı okutulmuştur. ${ }^{13}$ Memlûklular zamanında farklı mezheplere mensup halk için; Hanefî, Hanbelî, Şafiî ve Malikî mezheplerinin her biri için, birer kadı tayin edilirdi. Kadılık makamı, ilmî ve siyasî açıdan en üst mevki idi. Âlimler ve kadılar, derecelerinin yüksekliği oranında, sultanlar tarafından taltif ediliyorlardı. Âlimler genellikle halk ile sultanlar arasında köprü vazifesi görerek, kamuoyunun şikâyet ve arzularını sultanlara iletiyorlardı. Bu durum dînî özgürlükler bakımından olumlu olsa da, mezhep taassubunun tırmanması bakımından olumsuz etkiler ortaya çıkarmış, hatta bir mezhebe bağlı Müslümanın, diğer mezheplerden yararlanması, farklı mezheplere mensup Müslümanların birbirinin arkasında namaz kılmasının cevazı bile tartışılmıştır. ${ }^{14}$

Kelâm ilmi için mezheplerin karakteristiğinin tespiti açısından en önemli konu; mezheplerin kabul ettiği iman tarifleridir. Çünkü mezheplerin benimsedikleri iman tarifleri, imanla ilintili diğer konularda belirleyici olacaktır. Mezheplerin görüşlerini belli bir sistematiğe göre belirlemeleri ve bir görüşün, diğer bir görüşü gerektirmesi sebebi ile yapılacak iman tarifi, o mezhebin görüş bütünlügünün kavranması açısından çok önemlidir. Çünkü mezheplerin görüş sistematiği bir zincire benzetilirse, bu zincirin ilk halkası, iman tarifidir. Zaten, ilk fırkalaşmalar ve İslâm dünyasında ilk ayrılıklar küfür ithamları ile diğer bir deyişle dînî fırkaların benimsedikleri iman/küfür tanımlarının/anlayışlarının sonucu olarak ortaya çıkmıştır. Bu sebeple çalışmamız iman konusu etrafında şekillenecektir.

13 Kazım Yaşar Kopraman, "Baybars I", Türkiye Diyanet Vakfi İslâm Ansiklopedisi (İstanbul: TDV Yayınları, 1992) 5: 222.

14 Abdullah Kahraman, Ekmelüddîn el-Bâbertî́nin Fıkıh Usulündeki Yeri ve Usule Dair İki Eseri: et-Takrîr ve er-Rüdûd ve'n-Nükûd, Ekmelüddîn Bâbertî'yi Keșif Yolunda I. Ekmelüddîn Babertî Sempozyumu, (Erzurum, 28-30 Mayıs 2010). Edit.: Selçuk Coşkun. (Erzurum: Bayburt Üniversitesi Yayınları, 2014), 242. 
Tahâvî, eserinde imanla ilgili olarak "Iman lisan (dil) ile ikrar ve cenân (kalp) ile tasdik etmektir. Allah'ın Kur'an'da indirdiği şeylerin hepsi ile Allah'ın resulünden sahih olarak ortaya çıkan şeriat ve açıklamalarm hepsi haktır. Iman tektir. Iman ehli imanın aslı bakımından eşittir. Aralarındaki fazilet farkı korku, takva, nefsânî isteklere muhalefet etmek ve en güzel olanı yapmaktan kaynaklanmaktadır." ${ }^{15}$ demektedir. Tahâvî'nin bu cümleleri onun imanın tarifi, amellerin imana dâhil olup olmadığı meselesi, imanın artıp eksilmesi meselesi ve iman ehlinin imanlarının birbiriyle eşit olup olmadıkları meselesi olmak üzere imanla ilgili dört tartışma konusu hakkındaki görüşlerini özetlemektedir. Onun imanla ilgili bu ibareleri üzerine, şârihleri olan Bâbertî ve İbn Ebi'l-İzz'in yaptığı açıklamalar, beslendikleri ilmî geleneği ortaya koyması bakımından çok önemli bilgiler verecektir.

Öncelikle Tahâvî́nin iman konuları ile ilgili olarak yaptığı açıklamaların, Ebû Hanîfe' nin açılamaları ile tam bir örtüşme halinde olduğunu söylemek gerekir. Tahâvî'nin yaptığı iman tarifi, Ebû Hanîfe'nin el-Âlim ve'l-Müteallim ve $e l-F \imath k h u^{\prime} l-E k b e r$ 'inde yaptığı iman tarifi ile aynı tariftir. Ebû Hanîfe $e l-F \imath k-$ $h u^{\prime} l$-Ekber'de, Tahâvî'nin tarif ettiği şekilde, imanı kalp ile tasdik ve dil ile ikrar olarak tarif etmiştir. ${ }^{16} \mathrm{O}$, el-Âlim ve'l-Müteallim'de de imanla ilgili olarak insanları üç kategoriye ayırarak, dil ile ikrar etmeyenin kullar katında mü'min olmasa da, Allah katında mü'min olduğunu söyleyerek ${ }^{17}$ imanda vazgeçilmez unsurun tasdik olduğunu, ikrarın ise dünya ahkâmını icra için gerekli bir şey olduğunu vurgulamıştır. Yine Ebû Hanîfe'ye göre de, bütün mü' minler iman bakımından eşit, ama iman dışındaki marifet, yakin, tevekkül, muhabbet, korku, ümit gibi ameller bakımından birbirinden farklıdır. ${ }^{18}$ Görüldüğü üzere Ebû Hanîfe ve Tahâvî'nin eserlerindeki bu cümlelerinin birbirine yakınlığı, Ebû Hanîfe'ye atfedilen eserlerin ona ait olmadığını iddia ederek, Ebû Hanîfe'nin asıl fikirlerinin Tahâvî'nin $e l-A k i ̂ d e$ 'sinde dile getirildiği bu sebeple de el-Akîde metninin Ebû Hanîfe'nin itikadî görüşlerinin yegane muteber kaynağı olduğunu savunan, Selefî/ Vehhâbî iddiay $1^{19}$ da boşa çıkarmaktadır.

15 Ebû Ca'fer et-Tahâvî el-Hanefî, el-Akîdetü't-tahâviyye -beyânu akîdeti ehli's-sünneti ve'l-cemaa(Beyrut: Dâru İbn Hazm, 1995/1416): 21-22.

16 Ebû Hanife, el-Fıkhu'l-Ekber, (İmam-1 A'zamın Beş Eseri) terc. Mustafa Öz, (İstanbul: Marmara Üniversitesi İlahiyat Fakültesi Vakfı Yayınları, 2016) Arapça kısmı, 74.

17 Ebû Hanife, el-Âlim ve'l-Müteallim, (İmam-1 A'zamın Beş Eseri) terc. Mustafa Öz, (İstanbul: Marmara Üniversitesi İlahiyat Fakültesi Vakfı Yayınları, 2016), Arapça kısmı, 18.

18 Ebû Hanife, el-Fikhu'l-Ekber, 75.

19 el-Efgânî, Şemsuddin es-Selefî, Adâu'l-mâturîdiyye li'l-akîdeti's-selefiyye: el-mâturîdîyye ve mevgifühüm min tevhîdi'l-esma ve's-sıfat, (Taif: 1419/1998): 195-198; Muhammed b. Abdirrahman el-Humeyyis, İmam Eb̂̂ Hanîfe'nin Itikat Esasları, terc: Ahmet İyibildiren, Mustafa Öztürk, (İstanbul: Guraba Yayınları, 2013), 126, 129. 


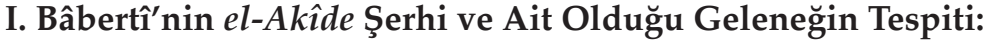

Bâbertî şerhinde öncelikle Tahâvî'nin metninde geçen ibareleri ele alarak, iman tarifinde geçen "cenan" kelimesinin kalp anlamına geldiğini söyledikten sonra, imanın hakiki anlamda mahiyeti hususunda ihtilaf olduğunu, İmam Mâturîdî'nin imanın hakiki anlamda kalp ile tasdik etmek olduğunu söylediğini nakletmektedir. Bâbertî daha sonra imanın mahiyeti hakkında şöyle demektedir: "Kalpteki şeyler gizli olduğundan dolayı, onlara dayanılarak bir hükme varılamaz. Bu sebeple şâri' olan Allah, ikrarı kalpteki hakkında delil olarak kabul edip, dünyadaki hükümlerin uygulanması için bir şart kılmıştır. Eğer bir kişi kalbiyle tasdik etse, ama diliyle ikrar etmese, Allah'in kalbinde olanı bilmesinden dolayı, Allah katında mü'min olur. Ancak imanina delalet eden ikrarm mevcut olmaması sebebiyle bizim katımızda mü'min olmaz. Biz, zahire göre hüküm veririz Ancak Allah görünmeyenlere göre hüküm verir. Şemsu'l-Eimme ${ }^{20}$ ve Fahru'l-İslâm Pezdevî̀ ${ }^{21}$ de dil ile ikrarı, tasdik gibi imanın asıl rüknü saymışlardır. Dil ile ikrar zâid bir rükün olup, zorlama durumunda düşebilir. Tasdik ise aslî bir rükün olup, hiçbir durumda düşmez. Kim kalbiyle tasdik edip bir özür olmaksızın dili ile ikrar etmezse, mü'min olmaz. Musannifin imanın kalp ile tasdik, dil ile ikrar olduğu şeklindeki sözü buna işaret etmektedir."22 Bu cümlelerinden Bâbertî́nin de Ebû Hanîfe gibi imanda asıl unsurun tasdik, ikrarın ise dünya ahkâmının icrası bakımından gerekli, aslî olmayan bir unsur olduğu şeklindeki görüşü kabul ettiğini söyleyebiliriz.

Ehl-i Sünnet kelâmının önemli temsilcisi İmam Mâturîdî, hem aklî, hem de naklî deliller sebebiyle, imanın oluşmasında etkin organın kalp olduğunu, kalpte tasdik ve marifetin gerçekleşebileceğini, ancak marifetin iman için yeterli olmadığını söylemektedir. Ona göre imanda vazgeçilmez unsur tasdiktir. İkrar ise asıl unsur değildir. ${ }^{23}$ Ebu'l-Muîn Nesefî; Mâturîdî ve Eş'arî'nin imanı kalb ile tasdik olarak tanımladıklarını, Ebû Hanîfe'nin de aynı görüşte olduğuna dair rivayetlerin olduğunu belirttikten sonra, kendisinin de aynı

20 Ebû Muhammed Abdulaziz b. Nasr el-Hulvânî. Rey'lilerin imamı ve bir hanefî fakih olup fıkıh kitabı olan el-Mebsût'un musanniflerindendir. H. 448'de vefat etmiștir. (Muhammed b. Muhammed b. Mahmud el-Bâbertî, Şerhu'l-akîdeti't-tahâviyye, thk: Abdusselâm b. Abdilhâdî Şennâr, (Beyrut: Dâru'l-Beyrûtî, 1430/2009): 98 (Muhakkikin Dipnotu: 1)

21 Fahru'l-İslâm Ebu'l-Usr Ali b. Muhammed b. Hüseyn el-Pezdevî. H. 482'de vefat etmiş hadis, tefsir ve kelâm âlimidir. Daha çok fıkıhçı kimliğiyle tanınmaktadır. Kelâm ilmine dair şöhret bulmamış Müyesser fi'l-Kelâm ve Şerhu'l-Fikhi'l-Ekber adında iki tane eseri vardır. (Bâbertî, Şerhu'l-akîdeti't-tahâviyye, 98 (Muhakkikin dipnotu: 2); Murteza Bedir, Ferhat Koca, "Ebu'l-Usr Pezdevî," Türkiye Diyanet Vakfi İslâm Ansiklopedisi (İstanbul: TDV Yayınları, 2007), 34: 266-264.

22 Bâbertî, Şerhu'l-Akîdeti't-Tahâviyye, 98.

23 Ebû Mansur el-Mâturîdî, Kitâbu't-terhîd, thk. Bekir Topaloğlu, Muhammed Ârûçî, (Beyrut: Dâru Sâdır, 2010), 481-484. 
fikirde olduğunu söyleyerek, imanın kalbin tasdiki olduğuna dair çeşitli istidlâllerde bulunmaktadır. ${ }^{24}$ Saffâr Buhârî́ye göre de imanın özü ve varlı̆̆1 sebebiyle kişiyi mü'min eden şey, kalp ile tasdiktir. İkrar, imanın özü olmamakla birlikte iman etmeye güç yetiren kişinin imanını ikrar etmesi gerekir. ${ }^{25}$ Ebu'l-Yusr Pezdevî, iman kelimesinin lügatte kesin olarak tasdik anlamına geldiğini, buradan hareketle şeriatta da kalp ile tasdik, dil ile ikrar anlamına geldiğini söylemektedir. ${ }^{26}$ Sâbûnî ise, imanın kalp ile tasdik olduğunu, dil ile ikrarın ise kalpteki imanın habercisi olması bakımından, dünya hükümlerinin icrası için gerekli bir şart olduğunu kabul ederek, muhakkik âlimlerin görüşünün de bu şekilde olduğunu haber vermektedir. ${ }^{27}$ Bu durumda Mâturîdî geleneğin, imanı kalbin tasdiki olarak tanımladığını, dil ile ikrarı ise, imanın özüne dâhil olmayan, ancak sosyal ilişkilerde Müslüman hükümlerinin yürütülmesi bakımından gerekli bir unsur olarak kabul ettiğini görüyoruz. Buna göre, bu konuda Mâturîdî gelenekle Bâbertî̀nin aynı görüşte olduğunun söyleyebiliriz.

Diğer taraftan Eş'arîler de imanı tasdik olarak kabul etmiştir. Eş'arî, Kur'an'ın nazil olduğu dilde imanın tasdik olduğunu, dinde de imanın Allah'1 tasdik etmek olduğunu söyleyerek, bu hususta bir görüş birliği oluştuğunu belirtmektedir. ${ }^{28}$ Bâkillânî de imanın hakikatinin tasdik olduğunu, tasdikin mahallinin kalp olduğunu söylemektedir. ${ }^{29}$ Cüveynî iman hakkında mezheplerin görüşlerini sıraladıktan sonra en doğru görüşün imanın Allah'ı tasdik etmek olduğunu, bunun delilinin de iman kelimesinin açık olan lügavî anlamı olduğunu söylemektedir. ${ }^{30}$ Râzî de, imanı selefleri gibi tanımlayarak,

24 Ebu'l-Muîn Meymûn b. Muhammed en-Nesefî, Tabstratu'l-edille fì usûli'd-dîn, tahk.: Muhammed el-Enver Hâmid Îsâ, (Kahire, 2011) 2: 1077; Kitâbu't-temhîd fì usuli'd-dîn, tahk.: Muhammed Abdurrahman eş-Şâğûl, (Kahire: el-Mektebetü'l-Ezheriyye li't-Türâs, 2006), 146.

25 Ebu'l-İshak es-Saffâr el-Buhârî, Telhîsu'l-edille li kavâidi'd-tevhîd, tahk.: Abdullah Muhammed Abdullah İsmail (Kahire, 2011), 685, 687.

26 Ebu'l-Yusr Muhammed el-Pezdevî, Usûlu'd-Dîn, thk Ahmed Hicâzî es-Sigâ, (Kâhire: 2003) 148.

27 Nureddîn es-Sâbûnî, Kitâbu'l-bidâye mine'l-kifâye fî̀ usûli'd-dîn, tahk.: Fethullah Huleyf, (İskenderiyye: Dâru'l-Ma'rife, 1969), 152.

28 Ebu'l-Hasan el-Eş'arî, Kitâbu'l-lum'a fìr-reddi ala ehli'z-zeyği ve'l-bid'a, tahk.: Hamûde Ğarâbe, (Kahire: 2010), 130.

29 Kâdî Ebu Bekir b. et-Tayyib el-Bâkıllânî el-Basrî, el-insâfu fî mâ yecibu i'tikâduhu velâ yecûzu'lcehlu bihi, tahk.: Muhammed Zâhid b. el-Hasan el-Kevserî, (Bask yy: Mektebetü'l-Ezheriyye Li't-Türâs, 2000), 52.

30 Ebul-Meâlî Abdulmelik el-Cüveynî, Kitâbu'l-irşâd ilâ kavâtti'l-edille fî usûli'l-i'tikâd. Tahk.: Esad Temîm. (Beyrut: Müessesetü'l-Kütübi'l-Sekafiyye,1985), 333, 334. 
delil olarak yine onlar gibi kelimenin lügat anlamını kullanmaktadır. ${ }^{31}$ Burada dikkat çeken husus, Eş'arîlerin de imanı Mâturîdîler gibi tanımlamasına rağmen, (Kerrâmiyye'nin imanın ikrar olduğu tezini çürütmeye çalışsalar da) tasdikin yanı sıra ikrarın gerekli olup olmadığı konusu üzerinde, Mâturîdîler gibi durmamalarıdır. Saffâr Buhârî’nin de bu duruma dikkat çektiğini ${ }^{32}$ görüyoruz. Bâbertî'nin imanda ikrarın durumunu, Mâturîdîler gibi tartışması, Bâbertî́nin ilk bakışta Eş'arîlerden ayrıştı̆̆ının, Mâturîdî kelâm geleneğine yakınlığının bir delili olduğunu söyleyebiliriz.

Amellerin imana dâhil edilmesi fikrinin, amelsiz birini imandan çıarması gerektiği eleştirisinden sonra, amellerin imana dâhil olmadığını açıklamaya çalışan Bâbertî'nin bu husustaki delili, Kur'an-1 Kerim'in birçok yerinde; "Şüphesiz ki, iman eden ve salih ameller işleyen kimseler..."(el-Meryem 19/96), "Gayba iman eden ve namazı ikâme edenler..."(el-Bakara 2/3), “Şüphesiz ki, Allah'ın mescitlerini Allah'a, ahiret gününe iman eden ve namazı ikame edenler imar eder."(et-Tevbe 9/18) buyurulması ve amellerin iman üzerine atfedilmesidir. Ona göre matuf, matufun aleyhden başkadır. Ayrıca iman, amellerin sıhhati için bir şarttır. "Kim mü'min olarak salih amel işlerse..." (et-Tâhâ 20 / 112) ayetinde görüldüğü üzere şart ile meşrut da birbirinden başkadır. Aynı şekilde Cebrail, peygamberimize imanın ne olduğunu sorduğunda peygamberimiz ona: "İman Allah'ı, meleklerini, resullerini, ahiret gününü, hayır ve şerri ile kaderi tasdik etmendir." diyerek, tasdiki gerektiren şeyleri belirterek cevap vermiştir. Eğer iman, tasdik ve ikrar ile beraber amellerden oluşsaydı, peygamberimiz onu muhakkak beyan ederdi. ${ }^{33}$

Yukarıdaki söylediklerinden Bâbertînnin amel ile imanın farklı şeyler olduğu hususunda, dil kâideleriyle istidlâl metodunu kullanarak Arap dil kaideleri gereği matuf ile matuf aleyhin başkalığı, şart ile meşrutun başkalığ1 kâidelerini ve Cibril hadisini kullanarak istidlâlde bulunduğunu, şerhini bu üç tür istidlâl üzerine yaptığını görüyoruz. Bu istidlâllerin özellikle ilk ikisi iman-amel farklılığı hususunda Mâturîdî geleneğin yaygın kullandığı istidlâl araçlarıdır.

İmam Mâturîdî'nin tefsirinde “Kim mü'min olarak salih amel işlerse..." (et-Tâhâ 20/112) ayetini açıklarken ayette imanın, amellerin kabulü için bir şart kılındığını söylemektedir. $\mathrm{O}$, bu ayetin iman isminin ameller olmaksı-

31 Fahreddin er-Râzî, Muhassalu efkari'1-mütekaddimîn ve'l-muteahhirîn mine'1-ulema ve'l-hukema ve'l-mütekellimîn, thk. Tâhâ Abbdurraîf Sa'd, (Ezher: ts), 237.

32 Saffâr Buhârî, Telhîsu'l-edille, 687.

33 Bâbertî, Şerhu'l-akîdeti't-tahâviyye, 99. 
zın kazanılacağına dair delil olduğunu söylerken, ${ }^{34}$ dilbilgisi kaidelerine göre şart ile meşrutun mugayereti kuralını kullandığını anlıyoruz.

Ebu'l-Muîn Nesefî, amel ile imanın farklı şeyler olduğu hususunda, öncelikle "Allah'ın mescitlerini Allah'a, ahiret gününe inanan, namazı ikame eden ve zekâtı verenler inşa ederler"(et-Tevbe 9/18) ayetini delil getirerek, namaz kılmak ve zekât vermek fiillerinin iman üzerine atfedildiğini, bundan dolayı da bunların farklı şeyler olduğunu söylemektedir. Yine "O kimseler ki, iman ettiler ve salih amel işlediler..."(el-Yunus 10/9) ayetini zikrederek, bu ayette de aynı şekilde amelin iman üzerine atfedildiğini bu sebeple farklı şeyler olduğunu belirtmektedir. ${ }^{35}$ "Kim mü' min olmak şartıyla salih amel işlerse, ameli boşa gitmez" (el-Enbiya 21/94) mealindeki ayeti açıklarken Nesefî, imanın bu ibarenin tümüne verilmiş bir isim olamayacağını söylemektedir. Çünkü, bu durumda imanın kendi kendisine şart olma durumu ortaya çıkacaktır. Bu ise batıl bir durum olacağından amel ile iman birbirinden farklı şeylerdir. ${ }^{36}$

Nesefî, amelin imandan olmadığının bir başka delili olarak da Cibril hadisini kullanmaktadır. Ona göre, bu hadiste imanın ne olduğundan bahsedilirken, sadece tasdik zikredilmiştir. İman, tasdikin ötesinde başka bir şey olsaydı, Cibril dinlerini öğretmek için değil, tersine mü'minlerin aklını karıştırmak için gelseydi, Hz. Peygamberin cevabını kısa tutarak Cibril'in "bunu yaptığım takdirde mü'min olur muyum?" sorusundan sonra "evet" diye cevap vermesi yalan, Hz. Peygamber de yalanci olurdu. ${ }^{37}$

Sâbûnî de aynı istidlâllere amellerin imandan olmadığını ileri sürmüştür. Çünkü Allah amelleri iman üzerine atfederek "O kimseler ki, iman ettiler ve salih amel işlediler..." (el-İnşikak 84/25) buyurmuştur. Dil kâidelerine göre matuf ile matufun aleyh birbirinden farklıdır. Aynı şekilde iman, amellerin geçerliliği için bir şarttır. Allah bu konuda, “Kim mü'min olmak şartıyla salih amel işlerse..."(et-Tâhâ 20/112) buyurmuştur. Şart ile meşrut birbirinden farklı şeylerdir. Diğer delil ise, Cibril hadisi diye meşhur olan hadiste yapılan iman tarifi ve Hz. Peygamberin, Cebrail'in "bunları yaparsam mü'min olur muyum?" şeklindeki sorusuna "evet" diye cevap vermesidir. ${ }^{38}$ Buna göre

34 Ebû Mansur el-Mâturîdî, Te'vîlâtu ehli's-sünne, thk. Mecdî Bâsellûm, (Beyrut: Dâru'lKütübi'l-İlmiyye, 2005), 7: 313.

35 Nesefî, Kitâbu't-temhîd, 147.

36 Nesefî, Kitâbu't-temhîd, 148.

37 Nesefî, Tabsıratu'l-edille, 2: 1081.

38 Sâbûnî, el-Kifâye fi'l-hidâye, Tah: Muhammed Ârûçî, (İstanbul: 2014), 355; Kitâbu'l-bidâye, 153. 
Mâturîdî geleneğin açıklamaları ile Bâbertî'nin açıklamaları arasındaki tam bir benzerlik olduğunu söyleyebiliriz. Bâbertî́nin açılamaları ile özellikle Sâbûnî'nin açıklamaları arasında ciddi benzerlik olduğu gözden kaçmamaktadır. Ebû Hanîfe'nin ilim geleneğiyle olan sıkı bağları, eserlerinde Ebû Hanîfe, Nesefî ve Sâbûnî'ye yaptığı atıflar ve Sâbûnî' nin eserlerinin ibarelerini neredeyse aynen yazmas ${ }^{39}$ onun beslendiği kelâmî geleneğin Mâturîdîlik olduğunu ortaya çıkarmaktadır.

Bâbertî, imanda artma ve eksilme olduğuna dair istidlâlde kullanılan “Allah'ın ayetleri okunduğu zaman imanlarını artırır."(el-Enfal, 8/2), "İmanlarını kat kat artırmaları için...." (el-Fetih 48 /4) gibi ayetleri de ele alarak şöyle değerlendirmektedir: "Bu ve benzeri ayetleri imanın, salih ameller ile saflığını nurunun parlaması ile artması üzerine hamledilir. Bu hususta Allah, "Allah kimin gönlünü İslâm'a açmışsa, o rabbi tarafından bir nur üzere değil midir?"(ez-Zümer 39/22) buyurmuştur. Söz konusu iki ayette geçen artışla kastedilen şey, imanın aslında olan bir artışa hamledilmemiştir. İman Tahâvî'nin "aralarında üstünlük farkı ve mertebelerindeki farklllk, imanin vasıflarında olan aydınlık, ziya ve yakinlerinin artması, takvalı amel etmeleri, kötülü̈ğü emreden nefs-i emmâreye muhalefet etmeleri, söz ve fiilleri bakımindan en güzel olanda sebat etmelerinden kaynaklanmaktadır." sözü de bu hususa işaret etmektedir." ${ }^{\prime 40}$ Buna göre Bâbertî, amellerin imanın özünde bir artma ve eksilmeye etki etmediğini, ancak imanın yakîni bakımından bir etkisinin olabileceğini kabul etmektedir. Onun bu açıklamaları Tahâvî'nin açıklamaları ile tamamen örtüşmektedir. Dolayısı ile Bâbertî'nin yaptığı şerh ana metne sadık kalınarak yapılan bir şerh çalışmasıdır.

Bâbertî'nin yukarda anlattıkları, Mâturîdî geleneğin görüşleriyle de örtüşmektedir. İmam Mâturîdî, "İman edip salih ameller işleyenler için bir bağışlanma ve büyük bir mükâfat vardır."(el-Fatır 35/7) ayetini açıklarken, bu ayetin iman edenlerin imanını, inkâr edenlerin de körlüğünü ve pisliğini artırdığını haber vermekte olduğunu; pisliğin mecazî pislik olduğunu, imanın artmasında da mecaz bulunduğunu, imandaki bu artışı nuru, vasfı, rahmeti ve burhanındaki artış olduğunu söylemektedir. ${ }^{41}$ Nesefî, Mü'minlerin ameller bakımından farklılaştığını, imanın özü olan tasdikte artıp eksilme olmayacağını, ayetlerde geçen imanın arttığına dair ibarelerin imanın özündeki artışa değil, yakînindeki artışa işaret ettiğini söylemekte-

39 Sâbûnî ile Bâbertî́nin metinlerindeki benzerlik için bk. Yunus ÖZTÜRK, Semerkand'dan Kahire'ye Hanefi Kültürün İzleri, İslâmî Araşttrmalar Dergisi, 27/3 (2016): 404-413.

40 Bâbertî, Şerhu'l-akîdeti't-tahâviyye, 102.

41 Mâturîdî, Te'vîlât, 7: 469. 
dir. ${ }^{42}$ Sâbûnî, Pezdevî ve Saffâr Buhârî gibi Mâturîdî ekolü âlimlerinin hepsinin aynı şekilde imanın özü olan tasdikte, amellerin artıp eksilmesiyle artma ve eksilmenin söz konusu olmayacağı, ancak imanın nuru, yakîni, parlaklığı ve meyveleri bakımından artış olabileceğini söylemektedirler. ${ }^{43}$ Buna göre bu konuda Bâbertî́nin, Tahâvî́nin ve Mâturîdî geleneğin aynı fikirde olduğunu söyleyebiliriz.

Bâbertî'ye göre iman, peygamberin Allah'tan getirmiş olduğu şeylerin tümünü tasdik etmekten ibaret olup, imanla mükellef olan kimseler, iman edilmesi gereken hususlar bakımından birbirlerinden farklı değildir. Sema ehlinden meleklerin, yeryüzü ehlinden insan ve cinlerin imanları, imanın özü açısından tektir. İmanın bu özü ise, Allah'ın tekliğini fiili ve zâtî sıfatlarının sabit olduğunu, iman edilmesi gereken diğer hususların hepsini toplu olarak tasdik etmektir. İşte mükellef olan herkesin eşit olduğu husus budur. Buna göre insanların imanının aslı, onların imanının aslı gibidir. Ancak sema ehli varlıkların ve peygamberlerin insanlardan birtakım üstünlükleri vardır. Bu üstünlük ise, imanın asılları olan tasdik üzerine zâid olan hususlarla ilgilidir. Çünkü Allah, peygamberleri nübüvvet ile insanlardan faziletli yapmış, yine aynı şekilde onların ibadet ve sevaplarını da diğer insanlardan üstün kılmıştır. Onlar Allah'ın emin kullarıdır ve insanlardan hiç kimse ibadet ve takva bakımından onlara denk olamaz. ${ }^{44}$

İmanın esas unsurunun tasdik olarak belirlenip imanda artma ve eksilme kabul edilmeyince, iman ehlinin imanlarının, tasdik bakımından eşit olması söz konusu olacaktır. Bu sebeple Ehl-i Sünnet, iman ehlinin imanlarının eşit olduğunu söylemiştir. Bu hususta Ebû Hanîfe'nin el-Âlim ve'l-Müteallim'inde "bizim imanımızın aslı ile meleklerin imanının aslı aynıdır. Zira biz Allah'ın vahdaniyetine, rab olduğuna, onun katından gelen her şeye tıpkı meleklerin, resul ve nebilerin tasdik ve ikrar ettikleri gibi iman ederiz." ${ }^{45}$ şeklindeki söylemi, Mâturîdî gelenek için bu hususta öncü bir görüş olmuştur. Zîra Pezdevî”nin “Bazısının imanı, nitelik yönünden bazısından daha üstündür. Mü'minler birbirine karşı bu şekilde üstünlük sağlarlar. Ebû Hanîfe "İmanım Cebrail'in imanı gibidir derim, ama onun imanına benzer diyemem. Çünkü "misl" (benzer) kelimesi stfatlarda eşitliği gerektirir. Benzetme edatı olan "ke" harfi cerri ise bunu gerektirmez."

42 Ebu'l-Muîn en-Nesefî, Bahru'l-kelâm, thk. Veliyyuddin Muhammed Salih Ferfur, (Şam: Mektebetü Dâru'l-Ferfur, 2000), 158.

43 Sâbûnî, el-Kifâye, 366; Pezdevî, Usûlu'd-dîn, 156; Saffâr Buhârî, Telhîsu'l-edille, 689.

44 Bâbertî, Şerhu'l-akîdeti't-tahâviyye, 101.

45 Ebû Hanîfe, el-Âlim ve'l-müteallim, 20. 
demiştir ${ }^{46}$ dediğini görüyoruz. Ebu'l-Berekât Nesefî de Ebû Hanîfe'yi referans göstererek “Bizim imanımız, Ebû Hanîfe'nin dediği gibi, meleklerin ve resullerin iman gibidir. Çünkü biz de, melekler ve resuller gibi Allah'ın vahdaniyetini, rubûbiyetini ve kudretini tasdik ediyoruz"47 demiştir. Tahâvî"nin de "İman tektir. İman ehli, imanın aslı bakımından eşittir. Aralarındaki fazilet farkı korku, takva, nefsân̂̂ isteklere muhalefet etmek ve en güzel olan yapmaktan kaynaklanmaktadır"48 dediği göz önünde bulundurulduğunda, Ebû Hanîfe, Tahâvî ve Mâturidî kelâmının ileri gelen âlimleri ve Bâbertî’nin aynı şeyler söylediğini, aynı gelenek içinde değerlendirilmesi gerektiğini görüyoruz.

\section{II. İbn Ebi'l-İzz'nin el-Akîde Şerhi ve Ait Olduğu Geleneğin Tespiti:}

İbn Ebi'l-İzz de öncelikle, imanın ne olduğu hususunda âlimlerin ihtilaf içinde bulunduğunu bildirmektedir. Buna göre, İmam Mâlik, İmam Şâfii, Ahmed b. Hanbel, İmam Evzâî İshak b. Rahaveyh, zahir ehli ve bazı kelâmcılar imanı kalp ile tasdik, dil ile ikrar, âzâlarla amel olarak kabul etmiştir. Ebû Hanîfe ve İmam Tahâvî, imanı kalp ile tasdik, dil ile ikrar olarak kabul etmiş, Mâturîdî de ikrarın aslî bir rükün olmayıp, zâid bir rükün olduğunu söylemiştir. Kerrâmiyye imanın dil ile ikrardan ibaret olduğunu, Cehm b. Safvân ve Kaderiyye' nin öncülerinden birisi olan Ebû Hüseyin es-Sâlihî de imanın kalp ile bilmek/marifeti olduğunu söylemiştir. ${ }^{49}$

Bâbertî'nin konuları özet geçmesine rağmen, İbn Ebi'l-İzz'in daha detaylı açıklamalara giriştiğini görüyoruz. Bu sebeple imanın mahiyeti ile ilgili yukarıdaki görüşleri tek tek değerlendirmektedir. İbn Ebi'l-İzz'e göre, Kerrâmiye'nin imanın ikrardan ibaret olduğuna dair kanaati yanlıştır. Çünkü bu görüş, münafıkların hakiki birer mü'min olmasını gerektirecektir. Allah'ın vaat ettiği azabı hak etmeleri sebebiyle, bu görüşün tutarsız ve bozuk olduğu açıktır. İmanı kalbin bilmesi/marifeti olarak tanımlayanların görüşünün bozukluğu da, Kerrâmiye'nin görüşünün bozuk oluşundan daha açıtır. Çünkü onların bu görüşü, Firavun ve kavminin iman ehli olmasını gerektirir. Zira onlar, inanmadıkları Hz. Mûsâ ve Hz. Hârun'un doğru olduğunu biliyor, ama iman etmiyorlardı. Bu hususta Allah, "Muhakkak iyi biliyorsun ki, bunları ancak, göklerin ve yerin Rabbi, apaçık deliller olarak indirmiştir."(el-İsrâ 17/102), "Ve onu, yakîn (kesin) olarak bildikleri (inandıkları) halde, nefisle-

46 Pezdevî, Usûlu'd-Dîn, 156.

47 Ebu'l-Berekât en-Nesefî, el-I'timâd fi'l-i'tikâd, thk. Abdullah Muhammed Abdullah İsmail, (Kahire: 2014), 381.

48 Tahâvî, el-Akîdetü't-tahâviyye, 22.

49 İbn Ebi'l-İzz, Şerhu'l-akîdeti't-tahâviyye, 313, 314. 
rine zulmederek ve büyüklenerek, bile bile inkâr ettiler. Öyleyse fesatçlların sonunun nasıl olduğuna bak!"(en-Neml 27/14) buyurmuştur. Yine Ehl-i kitap da, kendi çocuklarını bildikleri gibi Peygamberimizi biliyorlardı ama inat ederek mü'min değil, kâfir olmuşlardır. Ebû Talib'in durumu da böyledir. $\mathrm{O}$, Peygamberimizin dininin yeryüzündeki en hayırlı din olduğunu bilmiş, ama kınanıp sövülmekten çekindiğinden, İslâm'ı kabul etmemiştir. ${ }^{50}$

İbn Ebi'l-İzz, imanda asıl unsurun kalbin bilmesi olduğunu söyleyen Cehm b. Safvân'ın dolaylı olarak İblis'in de kâmil bir mü'min olduğunu söylediğini nakletmektedir. Çünkü İblis rabbini çok iyi biliyordu. Zira Allah'ın İblis'le ilgili olarak "'Rabbim, bana diriltilecekleri güne kadar süre ver' dedi..."(el-Hicr 15/36), “Dedi ki: Rabbim, beni azdırdığın için...”(Hicr 15/39) ve "'Senin izzetine andolsun ki, onların hepsini mutlaka azdıracağım.' dedi."(es-Sâd, 38/82) buyurması, İblis'in Allah'ı bildiğini göstermektedir. Eğer imanda aslî unsur Allah'ı bilmekse, Allah'ı en iyi bilen varlıklardan biri olan İblis, hakiki mü'min olmaktadır. Devamında İbn Ebi'l-İzz'in, Cehm b. Safvân'a daha sert yüklendiğini görüyoruz: "Cehm'e göre küfür, Allah'ı bilmemektir. Bu noktada rabbini bilmeme hususunda Cehm'den daha cahil birisi yoktur. Çünkü o, Allah'ın mutlak varlığını kabul etmiş ancak Allah'ın tüm sıfatlarını yok saymıştır. Bundan daha büyük bir cehalet olur mu? Bu durumda Cehm kendi şahitliği ile kâfir olmaktadır." ${ }^{51}$ Bu söyledikleri ile İbn Ebi'1-İzz, küfür ithamı üzerinden Allah'ın sıfatlarının hâricî varlığını reddedenlerin görüşlerinin yanlışlığını ortaya koymak istemektedir. Ancak Cehm b. Safvân gibi, Allah'ın sıfatlarını nefiyle suçlananların aslında Allah'ın sıfatlarını tamamen nefyetmedikleri, kadimlerin çoğalmasını önlemek adına bu sıfatların ifade ettiği mânâları değil, kadîm varlıklar olarak hâricî varlıklarını reddettikleri ${ }^{52}$ bir gerçektir. Bu ise aslında Allah'ın sıfatların tamamen nefyetmek anlamına gelmemektedir. İbn Ebi'l-İzz'in, Cehm b. Safvân'ın iman tarifini eleştirirken konuyu Allah'ın sıfatlarıyla ilişkilendirerek ele alması, Allah'ın sıfatlarını nefyeden Mu'tezile kelâmını ${ }^{53}$ eleştirmesi anlamı da taşımaktadır. Onun bu tavrı Kelâma karşı olan Selefî tavrın bir tezahürü olarak kabul edilebilir.

50 İbn Ebi'l-İzz, Şerhu'l-akîdeti't-tahâviyye, 314.

51 İbn Ebi'l-İzz, Şerhu'l-akî̀deti't-tahâviyye, 314

52 Kâdî Abdulcabbâr, Şerhu'l-usûli'l-hamse, çev.: İlyas Çelebi, (İstanbul: Türkiye Yazma Eserler Kurumu Başkanlığı Yayınları, 2013), 314 vd.

53 Cehmiyye'nin, Halku'l-Kur'an Sıfâtullah konuları ile ilgili fikirlerinden etkilendiği düşüncesiyle Mu'tezile'ye ve bu konuyu savunan kişilere "Cehmi" adı verilmiştir. Bu ifadeyi özellikle mihneden en çok etkilenen Ashabu'l-Hadis kullanmıştır. Bu sebeple Ebi'lİzz'in Cehm b. Safvan'a sıfatlar konusunda yaptığı eleştiriler Mu'tezile'ye yapılmış sayılır. (Osman Aydınlı, Akılcı Din Söylemi, Farklı Yönleriyle Mu'tezile Ekolü, (Ankara: 2010), 348.) 
Kerrâmîlerin imanın ikrar olduğu ve Cehm ve taraftarlarının da imanın marifet olduğu iddialarına cevap veren İbn Ebi'l-İzz, imanın mahiyeti ile ilgili olarak imanın kalp, dil ve organlarla mı yoksa kalp ve dil ile mi gerçekleştiği şeklinde iki seçenek kaldığı tespitini yapmakta ve kalan bu iki seçeneği değerlendirmektedir. İbn Ebi'l-İzz'e göre, iman kelimesinin sözlükte tasdik anlamına gediğini savunan Eş'arî ve Mâturîdî anlayış birkaç yönden yanlıştır:

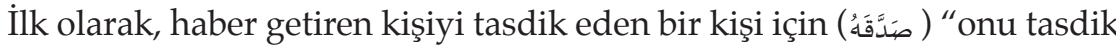

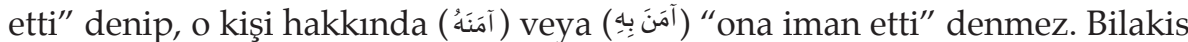
"ona inandı" denir. Yani "Amene" fiilinin "bi" harf-i cerri ile kullanılması ile "li" harf-i cerriyle kullanımı arasında fark vardır. "Bi" harf-i cerrli kullanım haber ile ilgili iken, "li" harf-i cerrli kullanım haberi getiren hakkında kullanılmaktadır. Tasdik ve iman kelimelerinin bu harf-i cerlerle kullanımında farklı anlamlar ortaya çıkmakta, bu kelimeler her zaman aynı anlama gelmemektedir. O halde bu kelimelerin bir yerde ayn anlamda kullanılması, bu iki kelime arasında mutlak bir terâdüf anlamına gelmez. ${ }^{54}$

İkinci olarak, iman ve tasdik kelimeleri, kullanım yerleri açısından da farklıdır. İman kelimesi sadece bilinmeyen gayb âlemine dair haberler ile ilgili kullanılırken; tasdik kelimesi hem görünür âlem, hem de gayb âlemi için kullanılır. Mesela görünür âlemle ilgili olarak güneşin doğduğunu söyleyen bir kimsenin doğru söylediğini beyan için "onu tasdik ettik" mânâsında "saddaknâhu" denir, ama "âmennâ lehû" denmez. Çünkü iman, gayba dair verilen haberlerde söz konusudur.

Üçüncü olarak ise, yalanlama anlamında "tasdik" kelimesinin zıddı olarak "tekzib" kelimesi kullanılırken, "tekzip" kelimesi "iman" kelimesinin zıddı olarak kullanılmaz. İman kelimesinin zıddı, küfür kelimesi olup, küfür ile tekzip aynı anlama gelmez. ${ }^{55}$

İbn Ebi'l-İzz'e göre, iman ile tasdik kelimeleri birbirinin aynı oldukları kabul edilse bile, tasdik sadece kalbin fiili değildir. Diğer fiiller ile de tasdik olduğu bilinmelidir. Bu hususta peygamberimiz "Gözler zina eder, onların zinası bakmakla olur. Bunu tasdik eden veya yalanlayan ise cinsel organdır." 56 buyurmuştur. Dolayısı ile ona göre namaz gibi ibadetler de, tasdikin farklı şekilleridir. ${ }^{57}$

\footnotetext{
54 İbn Ebi'l-İzz, Şerhu'l-akîdeti't-tahâviyye, 320.

55 İbn Ebi'l-İzz, Şerhu'l-akîdeti't-tahâviyye, 321

56 Ahmed b. Hanbel, el-Müsned, (Kahire: Müessesetü Kurtuba, ts) 2: 372; İbn Hibbân, Muhammed Ebû Hâtim et-Temîmî el-Büstî, Sahîhu İbn Hibbân, (Beyrût: 1993), 5: 267.

57 İbn Ebi'l-İzz, Şerhu'l-Akîdeti't-Tahâviyye, 321.
} 
İbn Ebi'l-İzz'in, Ehl-i Sünneti eleştiren, imanın tasdik anlamına gelmediğine dair ifadeleri ile İbn Teymiyye'nin söyledikleri örtüşmektedir. İbn Teymiyye'nin uzun uzun açıkladığ $1^{58}$ yukarıdaki üç hususun, İbn Ebi'l-İzz tarafından özet halinde anlatıldığı görülmektedir.

Lügat anlamından yola çıkılarak imanın sadece kalbin tasdiki olduğu şeklindeki söylemin yanlışlığına dikkat çeken İbn Ebi'l-İzz, Tahâvî'nin “İman dil ile ikrar ve kalp ile tasdiktir" ifadesini şerh ederken "Allah'ın insanlardan söz ve amel istediği" şeklinde bir fikir ortaya atarak söz ile kastedilen şeyin kalp ile tasdik, dil ile ikrar olduğunu söylemektedir. ${ }^{59}$ Bu söylemin aynısını Ehl-i Hadis geleneğinin önemli âlimlerinden İbn Teymiyye' nin eserinde görüyoruz. İbn Teymiyye imanla ilgili farklı tanımları, kendisinin tasdik ikrar ve amel şeklinde formüle ettiği iman tanımında birleştirme gayretiyle bazı yorumlarda bulunmaktadır. $\mathrm{O}$, bazı selef âlimlerinin imanı söz ve amel olarak tanımladığını söyledikten sonra, buradaki sözden kastın kalbin sözü ve dilin sözü olduğunu; amelden kastın da kalp ve âzâların ameli olduğunu söylemektedir. ${ }^{60}$ Ayn şekilde İbn Ebi'l-İzz'in de İbn Teymiyye'nin yaptığı gibi, Tahâvî'yi Seleften Ehl-i Hadisin iman anlayışına yaklaştırmak için "Allah'ın insanlardan söz ve amel beklediği" fikrinden hareket ederek, söz ile kastın kalp ile tasdik ve dil ile ikrar olduğu şeklinde zorlama bir yorum yaptığını görüyoruz. Ancak, Tahâvî'nin imanın dil ile ikrar ve kalp ile tasdik olduğu şeklindeki tanımına organlarla amel etmeyi eklemek suretiyle Tahâvî ve Hanefî akîdesini Ehl-i Hadis akîdesine yaklaştırabilmenin basit bir iş olmayacağ açıktır.

Ebû Hanîfe ve takipçisi Tahâvî'nin iman hakkındaki bariz görüşlerini hem eleştiren, hem de onların görüşleriyle Ehl-i Hadis görüşünü te'lif etmeye çalışan İbn Ebi'l-İzz, mürtekib-i kebire konusuna girerek bu te'lif çabasını sürdürmektedir. Ona göre imanın kalp, dil ve âzâlarla mı yoksa kalp ve dil ile mi gerçekleştiği şeklindeki iki seçenekten ilkini tercih eden Ehl-i Hadis âlimleriyle, ikincisini seçen Ebû Hanîfe ve takipçisi Tahâvî arasında aslında fark olmayıp ayrılık yüzeyseldir. O'na göre, her iki gurup da ameli imanın bir gereği olarak kabul etmiş olup; Ehl-i Hadis her ne kadar amelleri imanın tarifine dâhil etmişse de, büyük günah işleyen bir kimseyi tekfir

58 İbn Teymiyye, Kitâbu'l-Îman, (Dâru İbn Haldun, trs), 247-250; Kitâbu'l-îmânu'l-evsat, (Mecmu'u Fetâvâ'nın 7. cildinin içinde), thk. Âmir el-Cezzâr, Enver Elbâz, , (Dâru'l-Vefâ, 2005) 324-327.

59 İbn Ebi'l-İzz, Şerhu'l-akîdeti't-tahâviyye, 313, 315.

60 İbn Teymiyye, Kitâbu'l-İman, 151. 
etmemiş, durumunu Allah'a bırakmıştır. Bu durumda büyük günah işleyeni tekfir etmeden, mü'minliği veya kâfirliği hususunda hüküm vermeyip, hükmü Allah'a havale etmekle Seleften Ehl-i Hadis ile Ebû Hanîfe ve takipçisi Tahâvî aynı noktadadır. Burada ihtilaf İbn Ebi'l-İzz'e göre lafzîdir ve iki taraftan birinin görüşünün yanlış olduğunu göstermez. ${ }^{61}$ Bu noktada Ehl-i Hadis âlimlerinden yana olan kanaatini izhar eden İbn Ebi'l-İzz, amelleri imana dâhil etseler de, büyük günah işleyeni tekfir etmeyen Ehl-i Hadis'in, büyük günah işleyenden "mü'min" ismini kaldıran ${ }^{62}$ Mu'tezile ve Haricilerden ayrıldığı noktanın, büyük günah işleyeni iman dairesinden dışarı çıarmamak olduğunu zımnen belirtmektedir.

Eh-i Hadis âlimleri, imanın tasdik, ikrar ve amellerden oluştuğ ${ }^{63}$ hususunda hemfikirdir. Ancak günah işleyen bir kimsenin iman dairesinden çıkıp çıkmayacağı hususunda ihtilaf söz konusudur. Büyük günah işleyeni imandan çıktığını ileri süren Ahmed b. Hanbel, açık bir şekilde namaz kılmamanın kişiyi küfre götüreceğini, böyle bir kişinin de katlinin vacip olduğunu söylemektedir. ${ }^{64}$ Aynı fikirdeki İbn Mende, şirk gibi bazı günahların kişiyi imandan çıkardığını söylerken, çeşitli hadislere dayanarak bu günahlar arasında şirk koşmaktan başka yiyecek korkusundan dolayı çocuğunu öldürmek, komşusunun eşiyle zina etmek, ana-babaya kötü muamele etmek, yalancı şahitlik yapmak, sihir yapmak, faiz yemek, yetim malı yemek, savaştan kaçmak, mü'min kadınlara iftirada bulunmak gibi birçok günahı bu kapsamda saymaktadır. ${ }^{65}$ Hallâl da, imanda artıp azalma konusunu ele alırken, imanın amellerle tamamen yok oluncaya kadar azalacağını bildiren rivayetleri naklederek, kötü amelin kişiyi küfre düşürebileceğini dolaylı olarak söylemiştir. ${ }^{66}$ Diğer taraftan Abdurrahman Sâbûnî gibi bazı Ehl-i Hadis âlimleri ise büyük

61 İbn Ebi'l-İzz, Şerhu'l-akîdeti't-tahâviyye, 315.

62 Ebu'l-Hasan el-Eş'arî, Makâlâtu'l-islâmiyyîn ve ihtilâfu'l-musallîn, thk. Helmut Ritter, 3. Baskı (Wiesbaden: 1400/1980), 86, 270.

63 Ahmed b. Hanbel eş-Şeybânî, Usûlü's-sünne; Ebû Osman İsmail b. Abdurrahman es-Sâbûnî, Akîdetü's-selef ve ashâbi'l-hadîs, thk. Nâsır b. Abdurrahman b. Muhammed el-Cedî', (Riyad: Dâru'l-Âsıme 1998), 264; Ebû Muhammed Hasan b. Ali el-Berbehârî, Şerhu's-sünne, thk. Salih b. Fûzân, (Kahire: Mektebetü el-Hâdî el-Muhammedî, 2008), 93; Pezdevî, Usulu'd-dîn, 149; İbn Teymiyye, Kitâbu'l-î man, 264; Abdullah b. Abdurrahman el-Cebrîn, Şerhu Usûli'sSünne, (Riyad, H. 1420), 79.

64 Ahmed b. Hanbel, Usûlü's-Sünne, Baskı yy, ts. 1.

65 İbn Mende, Muhammed b. İshâk b. Yahyâ, Kitâbu'l-iman, thk. Ali b. Muhammed b. Nâsır el-Fakîhî, (Beyrut: Müessesetü'r-Risâle, 1985), 565 v.d.

66 Ebu Bekr Ahmed b. Muhammed b. Harun b. Yezîd el-Hallâl, es-Sünne, thk. Atiyye ezZehrânî, (Riyad: Dâru'-Râye, 1989), 584. 
günah işleyeni tekfir etmeyip, durumunun Allah'ın meşiyetinde olduğunu söylemişlerdir. ${ }^{67}$ Berbehârî de bu görüştedir. Berbehârî́nin, bu konu ile ilgili olarak Allah'a ortak koşmak, Kur'an'ı ve resulü yalanlamak gibi şirk kapsamına giren günahların, kişiyi imandan çıkaracağını, ama diğer günahların kişiyi imandan çıkarmayacağını, özürsüz olarak cuma namazını bile terk etse, kişinin bid'atçı ama mü'min olacağını söylediğini görüyoruz. ${ }^{68}$ İbn Ebi'l-İzz ise tevhid üzere ölen büyük günah sahiplerinin cehennemde ebedi kalmayacaklarını, tevhidi bozan şirk ve inkâr dışındaki günahların kişiyi kâfir etmeyeceğini söylemiştir. $O$, mürtekib-i kebîreyi tekfir etmez, durumunu Allah'ın dilemesine bırakır. ${ }^{69}$

Görüldüğü üzere, ilk olarak İbn Ebi'l-İzz'in iddia ettiği gibi mürtekib-i kebirenin durumu konusunda Ehl-i Hadis âlimleri hemfikir değildir. İkincisi, Ehl-i Hadis âlimlerinin kabul ettiği iman tarifi sebebiyle ameli imana dâhil etmeleri, mantıken mürtekib-i kebirenin küfrünü gerektirmektedir. Ehl-i Hadis'in bu konudaki yanlış tutumu Bâbertî'nin de dikkatini çekmiştir. Bâbertî, "İmam Şâfii fıskın fâsı̆̆ı imandan çıkarmayacağını söylemiştir ki, bu iddia yanlıştır. Çünkü İmam Şâfii'nin söylediği gibi iman tasdik, ikrar ve amelin toplamindan oluşunca, imandan bir parça olan amel olmadan "mü'min" isimlendirmesinin mantıken ortadan kalkması gerekir." ${ }^{\prime 70}$ diyerek Ehl-i Hadis'in içine düştüğü tezatı anlatmaktadır. Üçüncü olarak da, mürtekib-i kebîre hakkında hüküm vermeyip, durumunu Allah'a bıraktığını söyleyen Ehl-i Hadis, bu görüşüyle çokça eleştirdikleri Mürcie ${ }^{71}$ ile aynı konuma düşmektedir. Ayrıca Hanefî-Mâturîdî gelenek, büyük günah işleyen hakkında âsî mü'min hükmünü vermiş, onun hakkındaki hükmünü irca etmemiştir. Dolayısı ile İbn Ebi'l-İzz'in yukarıda zikrettiğimiz, Ebu Hanîfe ve Tahâvî geleneği ile Ehl-i Hadis geleneğinin arasındaki farkın yüzeysel olduğu şeklindeki görüşü pek tutarlı görünmemektedir.

Ehl-i Sünnet'in Kur'an'da iman ile amelin birbiri üzerine atfedildiği, bunun da bu ikisinin birbirinden farklı olduğunu gösterdiği şeklindeki görüşüne değinmektedir. İbn Ebi'l-İzz, bu şekildeki bir farklılığı itiraf etmekle

67 Ebû Osman Sâbûnî, Akîdetü's-selef, 276, 278. (Ayrica Sâbûnî, 279. sayfada İmam Şâfiî’nin de mürtekib-i kebîreyi tekfir etmediğini nakletmektedir.)

68 Berbehârî, Şerhu's-sünne, s. 135, 341.

69 İbn Ebi'l-İzz, Şerhu'l-akîdeti't-tahâviyye, s. 301, 355, 358.

70 Bâbertî, Şerhu'l-akîdeti't-tahâviyye, 99.

71 Ehl-i Hadis, irca fikrinden dolayı Mürcie'yi fitne olarak görmektedir. (Hallâl, es-Sünne, 562-564.) 
birlikte atfın aynı zamanda bu iki kavramın hüküm bakımından ortak olmasını gerektirdiğini söylemektedir. Farklılığın çeşitlerini anlattıktan sonra da, kalpte imanın bulunmaması durumunda amellerin iman olmayacağı, kalbin imanı ile birlikte olan amellerin ise iman olacağı sonucuna varmaktadır. $\mathrm{Bu}$ görüşünü de “Ben size sadece Allah'a imanı emrediyorum. Allah'a imanın ne olduğunu biliyor musunuz? Tek olarak Allah'tan başka ilah olmadığına, bir ortağının bulunmadığına şehadet etmeniz, namazı ikame etmeniz, zekâtı vermeniz ve ganimetlerin beşte birini dağıtmanızdır."72 mealindeki bir hadisle delillendirmektedir. ${ }^{73} \mathrm{Bu}$ istidlâlin aynısını İbn Teymiyye de yapmaktadır. İbn Teymiyye "Kur'an'da bir şeyin başka bir şey üzerine atfedilmesi atfedilen şeylerin farklılığını gerektirdiği gibi hükümleri hususunda müşterek olmalarını da gerektirir." ${ }^{\prime 74}$ şeklinde bir başlık altında örnekler vererek atfedilenler arasındaki ortaklığı ispatlamaya çalışmaktadır. Gerçekleştirmek istediği şey ise, Ehl-i Sünnetin ayırmaya çalıştı̆̆ iman ile ameli, aynı argümanı kullanarak birbirinden ayrı olamayacak iki rükün olarak okuyucuya sunmaktır. Onların bu çabasının altında yatan sebep ise, Ehl-i Sünnet kelamcılarının amelleri imanın gereği ama imandan farklı görerek, iman ve amel arasındaki bağı görmezden gelen yaklaşımlarına duydukları tepki vardır. İbn Ebi'l-İzz takip ettiği Ehl-i Hadis çizgisi sebebiyle, bundan rahatsızlık duymuş ve iman ile amel arasındaki bağlantının Ehl-i Sünnet kelamcılarının düşündüğünden daha güçlü olduğunu göstermeye çalışmıştır. Dolayısıyla İbn Ebi'l-İzz'in, İbn Teymiyye gibi Selefî Ehl-i Hadis geleneğine dayanan bir çaba içinde aynı açıklamaları yaptıklarını söyleyebiliriz. İbn Ebi'l-İzz amellerin imana dâhil olduğu görüşünü delillendirirken "İman yetmiş küsur şubedir. En üstünü "Lâ ilâhe illallah" demek, en zayıfı da insanlara rahatsızlık veren şeyleri yoldan uzaklaştırmaktır."75 "Hayâ imandan bir şubedir."76, İman bakımından en kâmil mü'min ahlak bakımından en güzel olanıdır."77 ve "Sade bir hayat sürmek imandandır." ${ }^{78}$ hadisleri ile istidlâlde bulunmaktadır. Ona göre imanın birçok şubesi vardır. Namaz, oruç, hac, zekât, hayâ, tevekkül, Allah'tan korkmak,

72 Muhammed b. İsmail Ebu Abdullah el-Cu'fî̀ el-Buhârî, Sahîhu'l-Buhârî, thk. Mustafa Edip, (Beyrut: 1987) İman, 38.

73 İbn Ebi'l-İzz, Şerhu'l-akîdeti't-tahâviyye, 329.

74 İbn Teymiyye, Kitâbu'l-îman, 152.

75 Ahmed b. Hanbel, Müsned, 2: 414.

76 Önceki hadisin bir bölümüdür.

77 Ahmed b. Hanbel, Müsned, 2: 250.

78 İbn Mâce, es-Sünen, Tah: Muhammed Fuad Abdulbâkî, (Beyrut: Dâru'l-Fikr, ts), Zühd, 4; Ebû Davûd, es-Sünen, (Beyrut: Dâru Kütübi'l-Arabî, ts), Teraccul, 1. 
Allah'a yönelmek, yolda rahatsızlık veren şeyi yoldan uzaklaştırmak gibi ameller de, imanın birer şubesi olup imandandır. Bu şubelerden bazılarının yokluğu imanı yok eder, bazılarının yokluğu ise imana zarar vermez. Mesela şahadet getirmemek imanı yok eden bir iman şubesi iken, yoldan rahatsızlık veren şeyi uzaklaştırma şubesinin yokluğu imanı yok etmez. İmanın şubelerinin aynısı gibi, küfrün de şubeleri vardır. ${ }^{79}$

Amelleri imana dâhil etmeye çalışan İbn Ebi'l-İzz, Ebu'l-Muîn Nesefî'nin imanın yetmiş küsur şube olduğuna dair bu hadis hakkındaki değerlendirmelerini de aktarmakta ve Nesefî́nin yaptığı açıklamaları çürütmeye çalışmaktadır. Çünkü Ehl-i Hadisin amellerin imana dâhil olduğuna dair kullandığı delillerden birisi “İman yetmiş küsur şubedir. Bunların en üstünü “Lâ ilâhe illallah" demek, en alt mertebesi ise yolda insanlara zarar veren şeyi ortadan kaldırmaktır" ${ }^{\prime 0}$ hadisidir. ${ }^{81}$ İbn Ebi'l-İzz'e göre, Nesefî, bu hadisi rivayet eden râvinin, rivayetin başında imanın yetmiş küsur veya altmış küsur şube olduğunu söyleyerek, kendisinin zan ve gaflet içinde olduğunu gösterdiğini söylemiştir. Nesefî́ye göre Allah'ın resulü böyle önemli bir hususta şüpheye düşerek tereddütlü söz söylemez. Ayrıca, bu rivayet kitaba da muhaliftir. ${ }^{82}$ İbn Ebi'l-İzz bu değerlendirmesi sebebiyle, Nesefî'yi alaylı bir şekilde eleştirmektedir: "Nesefî râvinin gafletini ve hadisin kitaba muhalif olduğunu iddia ederek hadise karşı çıkmıştır. Bu eleştiri ne kadar acayiptir? Râvinin tereddüt etmesi hadisi iyi öğrenememiş olması anlamına gelmez. Kaldı ki Buhârî, şüphe bildirmeksizin "imanın atmış küsur şube" olduğunu nakletmiştir. Hadisin kitaba aykırı oluşuna gelirsek, hadiste kitaba aykııllığına dair bir şey olmayıp, bilakis Kur'an'da bu hadisi destekleyen birçok ayet vardır. Bu iddia sadece taklit ve taassubun kötü bir meyvesidir." ${ }^{83}$ Ebu'l-Muîn Nesefî́nin konu ile ilgili yazdıklarını incelediğimizde Nesefî̀nin, aynı yerde bu hadisle amel etmemesine sebep olarak başka şeyler de söylediğini görüyoruz. Nesefî’ye göre bu hadiste râvinin gafleti veya şüphesi olmasa veya kitaba muhalefeti söz konusu olmasa dahi, itikadî konularda bu hadisle amel edilmez. Çünkü bu hadis haber-i vahiddir. Diğer taraftan hadisin anlattıkları da mantıken geçersizdir. Çünkü bu hadiste mesela "Lâ ilâhe illallah" sözü, imanın en üstün şubesi, yani imandandır. Mantık kurallarına göre, mürekkep bir varlığın bir parçası, o şeyin tümü demek değildir. Her

79 İbn Ebi'l-İzz, Şerhu'l-akîdeti't-tahâviyye, 322-323,

80 Ahmed b. Hanbel, Müsned, 2: 414.

81 İbn Teymiyye, Kitâbu'l-îman, s. 178; Hallâl, es-Sünne, 587.

82 Nesefî, Tabsıratu'l-Edille, 2: 1083.

83 İbn Ebi'l-İzz, Şerhu'l-akîdeti't-tahâviyye, 324. 
bir parça mürekkeb varlığın ismi, hükmü olamaz. ${ }^{84}$ Buna göre İbn Ebi'l-İzz'in Nesefî' nin yazdıklarını sadece cevabını verebileceği kadarını zikrederek eksik aktardığını, bu durumun da İbn Ebi'l-İzz'in mezhebî taassupla hareket ettiğinin güzel bir örneğini oluşturduğunu söyleyebiliriz.

Amelleri imana dâhil eden ve bunun doğal bir sonucu olarak da, imanda artma ve eksilmeyi kabul eden İbn Ebi'l-İzz'in görüşleri, Ehl-i Hadis geleneği ile örtüşmektedir. ${ }^{85}$ Bu konudaki görüşünü "Ayetleri onlara okunduğunda, bu onların imanını artırdı." (el-Enfal 8/2), "Allah hidayete erenlerin hidayetini artırır.” (el-Meryem 19/76), “O, imanlarına iman eklemeleri için Mü'minlerin kalplerine huzuru indirendir."(el-Fetih 48/4), "Onlar o kimselerdir ki, insanlar kendilerine 'Düşmanlarınız size karşı bir ordu hazırladı. Onlardan korkun' deyince, bu onların imanlarını artırdı..."(Âl-i İmran 3/173) mealindeki ayetleriyle delillendirmektedir. Bu ayetleri yorumlarken Ehl-i Sünnet âlimlerinin "Peygamberin sağlığında nâzil olan her ayete iman etmek gerektiği için, her gelen ayet mü' minlerin imanını artırmıştır." şeklindeki yorumunu ${ }^{86}$ İbn Ebi'lİzz, bu ayetin insanların söylediği sözü naklettiğini ve bu ayette teşrii bir artış olmadığını söyleyerek eleştirmektedir. ${ }^{87}$ Ancak kanaatimize göre, müellifin bu eleştirisi, kendisinin bu konuda Ehl-i Sünnetin bazı görüşleri gözden kaçırdığını göstermektedir. Çünkü inen her ayetin konusu ne olursa olsun, ne anlatırsa anlatsın, o ibarelerin (teşri değerinden bağımsız olarak) Allah katından gelen ayetler olduğu hususunda iman şarttır. Dolayısı ile Ehl-i Sünnet mantığına göre, her nazil olan ayet, konusundan bağımsız olarak bir iman konusu olmakta, böylece de imanda bir artış olmaktadır. Buna göre İbn Ebi'lİzz'in, Ehl-i Sünnet'in bu değerlendirmelerini gözden kaçırdığı veya bunları ele almaya değer görmediği tespitini yapmamız yerinde olacaktır.

Amellerin veya ilmin artması ve eksilmesi ile imanın da artıp eksileceği fikrini benimseyen İbn Ebi'l-İzz, bu görüşünü amellerin imanın gereği olduğu fikrine de dayandırmaktadır: "Kalp ve organlarm amelde bulunmasın gerektiren tasdik, azalarla amelde bulunmayı gerektirmeyen tasdikten daha üstündür. Sahibinin kendiyle amel ettiği ilim de, sahibinin amel etmediği ilimden üstündür. Gerekli olan bir şey ortaya çıkmıyorsa, bu, onu gerektiren şeyin zayıflı̆̆na delildir. "188

84 Nesefî, Tabsıratu'l-edille, 2: 1083.

85 Ehl-i Hadis'e göre imanın artıp eksildiğine dair bk. Ahmed b. Hanbel, Usûlü's-sünne.; Berbehârî, Şerhu's-sünne, 413; Ebû Osman Sâbûnî, Akîdetü's-selef, 264-265; İbn Teymiyye, Kitâbu'l-Îman, 195; Abdullah Cebrîn, Şerhu usûli's-sünne, 79.

86 Nesefî, Bahru'l-kelâm, 158; Sâbûnî, Kitâbu'l-bidây, 155.

87 İbn Ebi'l-İzz, Şerhu'l-akîdeti't-tahâviyye, 325.

88 İbn Ebi'l-İzz, Şerhu'l-akîdeti't-tahâviyye, 317. 
İbn Ebi'l-İzz, imandaki bu artma ve eksilmeyi imanın nurundaki bir artış olarak ortaya çıktığını söylemekte, imanın nurundaki artışı da, ilim ve amele bağlamaktadır. Onun imanın artıp eksildiğine dair verdiği örnekler de önemlidir. İbn Ebi'l-İzz, imandaki farklılığı anlatırken ilk olarak “bir haberle hakkında bilgi sahibi olunan şey, gözle görülen şey gibi değildir." ${ }^{89}$ hadisini delil getirmiştir. Diğer delili ise, Hz. Musa ile ilgilidir. Buna göre, Hz. Musa halkının bir buzağıya taptığına dair haberi duyunca değil de, gelip onları o hal üzere görünce şaşırarak elindeki Tevrat levhalarını yere atmıştır. Yani ilk inanç hali ile sonraki inanç durumu farklıdır. ${ }^{90}$ İbn Ebi'l-İzz'e göre, imandaki farklılaşmanın bir göstergesi de icmâlî iman ile tafsîlî imanın derecelerinin farklı olmasıdır. Yani, İslam'a yeni girmiş birinin yaptığı icmâlî iman ile zamanla ibadetleri öğrenip, ibadetlerin farziyetine inanıp, amel eden birinin iman derecesi farklıdır. Ona göre, imanda artma ve eksilme olacağına dair bir delil ise, Bakara Sûresinin 260. ayetidir. Bu ayete göre Hz. İbrahim Allah'a ölüleri nasıl dirilttiğini sormuş, Allah'ın "inanmadın mı?" sorusu üzerine de "İnandım, ancak kalbimin mutmain olması için bunu istiyorum" demiştir. ${ }^{11}$ Yani Hz. İbrahim, imanının kemale ermesi için bunu istemiştir. Görüldüğü üzere Ebi'l-İzz'in ileri sürdüğü bu deliller, imanın amellerle değil de ilim bakımından yani tasdikin yakîni bakımından artmasına delil olmaktadır. Tartışmalı olan konu, imanın amellerle artıp eksilmesi meselesi olup ${ }^{92}$ Ebi'l-İzz buna değinmemektedir. İmanın (ameller yönüyle değil de) yakîn ve parlaklık açısından artabileceği Ehl-i Sünnetin her iki ekolü tarafından da zaten kabul edilmektedir. Ehl-i Sünnetin her iki ekolünün karşı çıtığı, imanın amellere bağlı olarak artıp eksilmesidir. ${ }^{93}$

Tahâvî"nin "iman tekdir ve iman ehli imanın özünde eşittir. Aralarındaki üstünlük, korku, takva, nefsî arzulara uymama ve en güzel olanı yapmak bakımındandır." ${ }^{94}$ ifadesini ele alan İbn Ebi'l-İzz, "Kelime-i tevhidi kabul edenlerin kalplerinde Allah'tan başkasının anlayamayacağı nur farklılığı vardır. Kiminin kalbinin nuru güneş gibi iken kimininki parlak bir yıldız gibidir. Kimininki büyük bir meşale, parlak bir kandil gibi, kimininki de zayıf bir kandil gibidir. Bu sebeple imanından kaynakla-

89 Ebu Muhammed Abdülhak İşbilî, el-Ahkâmu'ş-şeriyyeti'l-kübrâ, thk. Ebu Abdullah Hüseyin b. Akâşe, (Riyâd, 2001), 1: 81 .

90 İbn Ebi'l-İzz, Şerhu'l-akîdeti't-tahâviyye, 318.

91 İbn Ebi'l-İzz, Şerhu'l-akîdeti't-tahâviyye, 318.

92 Pezdevî, imanda artışla ilgili tartışmanın imanın zâtı ile ilgili olduğunu, imanın sıfatları bakımından artma ve eksilmenin olacağını söylemektedir. (Pezdevî, Usûlu'd-dîn, 156)

93 Sâbûnî, el-Kifâye, 366; Saffâr Buhârî, Telhîsu'l-edille, 689; Pezdevî, Usûlu'd-dîn, 156.

94 Tahâvî, el-Akîdetü't-tahâviyye. 22. 
nan bu nurlar, kıyamet gününde imanları miktarınca, ilim ve amel bakımından imanın ve tevhidin nuru kadar onların önlerinde ortaya çıkacaktır." ${ }^{\prime 95}$ diyerek, Tahâvî'nin mü'minlerin imanın özü bakımından eşit olduğu görüşünü reddedercesine, doğrudan amelleri de dâhil ettiği imanların farklı farklı olduğunu, bu farklılığın ancak Allah tarafından bilinebilen imanlarının nuru bakımından olduğunu söylemekte ve bu nurun derecesini ise amel ve ilim bakımından farklılaşmaya bağlamaktadır. Buna göre Tahâvî'nin bahsettiği imanın özünde eşitlik ortadan kalkmakta, ilim ve amel mertebelerindeki farklılık imanın özüne dâhil olduğu için özü bakımından imanda eşitlik söz konusu olmamaktadır. İbn Ebi'l-İzz'in imanın nuru bakımından artacağını söylemesi, bu artışı da amel ve ilimdeki artışa bağlaması, sahip olduğu Ehl-i Hadis görüşlerini Tahavî́nin görüşleri üzerinden yansıtmaya çalıştığının delili olması bakımından önemlidir.

Ebu'l-Leys Semerkandî, Tevbe Sûresinin 124. ve 125. ayetlerini açıklarken, Ebû Hureyre'den naklen zikrettiği "Sakîf'liler peygamberimize gelerek 'Ey Allah'ın resulü! İman artıp eksilir mi?' diye sormuşlar, O da “Hayır, iman kalpte tekâmül etmiştir. İmanın artması da eksilmesi de küfürdür." ${ }^{96}$ şeklindeki rivayeti, imanda artma ve eksilme olmayacağına delil olarak kabul etmiştir. ${ }^{97} \mathrm{Bu}$ hadisi, râvîlerini eleştirerek reddeden İ̉n Ebi'l-İz, diğer taraftan imanın şubeleri hadisi, şefaat hadisi, kalbinde zerre kadar imanı olanlar hakkında söylenen v.b. hadisleri ve bir takım sahabe kavillerini delil olarak kullanmaktadır. ${ }^{98}$ İbn Ebi'l-İz, imanın artıp eksileceğine dair görüşünü delillendirirken, Hz. Peygamberin kadınların akıl ve din bakımından eksik olduklarını söylediğini, ${ }^{99}$ bunun da imanda azalma ve artmaya delil olacağını söylemektedir. ${ }^{100}$ Onun bu görüşü, bizim için İbn Ebi'l-İzz'in dâhil olduğu geleneğin, hadis usulü açısından içinde bulunduğu durumun açık bir göstergesi niteliğindedir.

İbn Ebi'l-İzz'in, şerhinde Ehl-i Sünnet'i eleştirdiği hususlardan biri de, iman ehlinin imanlarının eşit olup olmadığı meselesidir. Biri “Allah'ın kullarından söz ve amel istediği" diğeri de "kalbiyle tasdik edip diliyle ikrar eden,

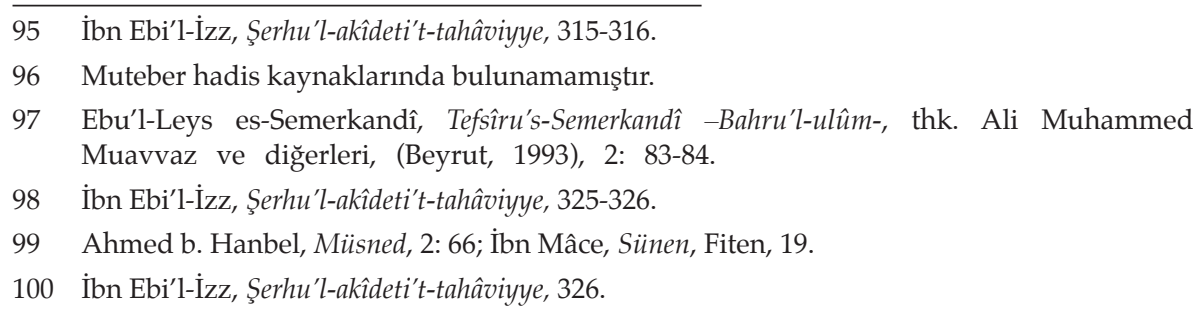

Hitit Üniversitesi İlahiyat Fakültesi Dergisi, 2018/1, c. 17, sayı: 33 
ama amelde bulunmayan birinin Allah'a ve resulüne isyan ederek azabı hak ettiğì" şeklinde iki icma zikreden İbn Ebi'l-İzz, amel ile iman arasındaki bağı da kullanarak, bunların birbirinden ayrılmaz şeyler olduğu, ayıranların ise bir aşırılık içinde olduğu düşüncesini şöyle açıklamaya çalışmaktadır: "Amellerin imana dâhil olmadığını söyleyenlere göre, iman sadece tasdikten ibaret olunca, onlardan "Benim imanım Ebû Bekir'in, Ömer'in, hatta nebilerin, resullerin, Cebrâil'in, Mikâil'in imanı gibidir" diyenler vardır. Bu söz bir aşırllıktır. Küfür ve iman, körlük ve görmeye benzer. Şüphesiz görenlerin görmelerinde farklılılar vardır. Aydınlıkta da karanlıkta da göremeyenler vardır. Kimisi ancak kalın çizgileri görebilirken, kimisi de bir mercek vb. aletlerle görebilir. Kimi çok yakından görebilirken kimi de bunun zıddına uzaktan daha iyi görebilir." 101 İbn Ebi'l-İzz'e göre, imanlarda farklılıklar kaçınılmaz olup, bu farklılıklar amellerin imana etki etmesinden kaynaklanmaktadır. Bir aşırılık ortaya çıkaracağından amellerin imana dâhil olmamas1 düşünülemez. $\mathrm{O}$, bu görüşüyle de Ehl-i Hadis ile aynı görüşte olduğunu göstermektedir. Meşhur Ehl-i Hadis âlimi Ebû Osman Sâbûnî de Ehl-i Sünneti eleştirirken "Allah, "benim imanım Yahyâ $b$. Yahyâ'nın"102 imanı gibidir veya Ahmed b. Hanbel'in iman gibidir" demeye cevaz vermemiştir. Oysaki onlar "benim imanım Cebrâil'in imanı gibi, Mikâil'in imanı gibidir." demektedirler." ${ }^{103}$ Ancak Ebu Hanîfe'nin "bizim imanımızın aslı ile meleklerin imanımın ash aynıdır. Zira biz Allah'ın vahdaniyetine, rab olduğuna, onun katından gelen her şeye tıpk meleklerin, resul ve nebilerin tasdik ve ikrar ettikleri gibi iman ederiz."104, Tahâvî' nin de "İman tektir. İman ehli, imanın aslı bakımından eşittir. Aralarındaki fazilet farkı korku, takva, nefsânî isteklere muhalefet etmek ve en güzel olanı yapmaktan kaynaklanmaktadır."105 dediği göz önünde tutulursa, İbn Ebi'l-İzz'in yukarıda yazdıklarını, görüşlerini şerh ettiği Tahâvî ve Ebû Hanîfe'ye rağmen yazdığını tespit etmemiz gerekir. Bu durumda İbn Ebi'l-İzz'in yaptığı çalışmanın, alışılmış bir şerh çalışması olmadığını, Tahâvî ve Ebû Hanîfe' nin görüşü ile Ehl-i Hadis âlimlerinin görüşünü uzlaştırmaya çabasının çelişkili bir ürünü olduğunu söyleyebiliriz.

101 İbn Ebi'l-İzz, Şerhu'l-akîdeti't-tahâviyye, 315.

102 Asrının meşhur Ehl-i Hadis âlimi Yahyâ b. Yahyâ b. Bekir et-Temîmî en-Nisaburî. H. 142 'de doğmuş, H. 226'da Nişabur'da ölmüştür. İmam Malik'in tabakasından olup ondan hadis almıştır. Buhârî ve Müslim de ondan hadis almıştır. Ahmed b. Hanbel onun için "Horasan'dan onun gibi biri daha çıkmadı" demiştir. (Ebû Osman Sâbûnî, Akîdetü's-selef ve ashâbi,'l-hadîs, 201, Muhakkikin dipnotu.)

103 Ebû Osman Sâbûnî, Akîdetü's-selef ve ashâbi,'l-hadîs, 272.

104 Ebû Hanife, el-Âlim ve'l-müteallim, 20.

105 et-Tahâvî, el-Akîdetü't-tahâviyye, 21-22. 


\section{Sonuç}

Gerek Bâbertî́nin, gerekse İbn Ebi'l-İzz'in yaşadığı dönem, İslâmî ilimlerin tekâmül ettiği, mezheplerin sistemleşerek Müslümanın hayatında belirleyici duruma geldiği bir dönemdir. Diğer bir deyişle içinde yaşadıkları dönem, ictihattan ziyade, taklidin ön planda olduğu bir dönemdir. Aslında yeni eserler yazmak yerine önceki üstatlarının eserlerini ele almak, görüş ve birikimlerini bu eserler üzerinden okuyucuya sunmak böyle dönemlerin bir özelliği olarak kabul edilebilir.

Bâbertî’nin ilk Hanefî itikad metinlerinden birini şerh ederek insanların istifadesine sunması, onun sadece fıkıh ve fıkıh usûlünde değil, kelâm alanında da yetkin bir âlim olduğunu gösterir. Bâbertînnin, Ebû Hanîfe'nin el-Vasiyye ve el-Fıkhu'l-Ekber'ine şerhler yazması, Hanefîliğin tercih edilmesi gereğini anlatmak için ayrı bir eser yazması, Hanefî fikirlerin ilk temsilcisi gördüğü Tahâvî'nin akîde'sini şerhetmesi, eserlerinde "Ebû Hanîfe'nin de dediği gibi..." şeklindeki ifadelerle onun görüş ve eserlerine atıflarda bulunması, Ebû Hanîfe'nin, Bâbertî'nin fikir dünyasında önemli bir yere sahip olduğunu göstermektedir. Eş'arîlerle Mâturîdîlerin farklılaşttğg konularda Mâturîdîlerin görüşünü benimseyen Bâbertî, kendini Ebû Hanîfe'nin mensubu olduğu bu kelam ekolüne mensup hissetmiştir. Biz de çalışmamızda bunu doğrulayan kanaatlere ulaştık. Onun iman konusu hakkında yaptığı açıklamalarla Ebû Hanîfe, Mâturîdî, Ebu'l-Muîn Nesefî, Pezdevî ve Sâbûnînnin yaptı̆̆ı açıklamaların tam örtüştüğünü, bu kelam silsilesinin temsil ettiği Mâverâünnehir Mâturî̀î kelam ekolüne mensup olduğunu, Ebû Hanîfe ve Tahâvî́yi de bu ekolün ilk temsilcileri olarak kabul ettiğini tespit ettik. Yaptığı bu şerh çalışması boyunca Ebû Hanîfe ve Tahâvî’yi aynı paralelde değerlendirerek, ana metni mecrasında ve Mâturîdî geleneğe uygun olarak şerh etmiştir.

Amelî bakımdan Hanefî mezhebine mensup olan İbn Ebi'l-İzz, yetiştiği ortam sebebiyle itikâdî olarak Seleften Ehl-i Hadis akîdesini benimsemiştir. Daha önce belirttiğimiz, Ebû Hanîfe'nin asıl fikirlerinin Tahâvî'nin elAkîde'sinde dile getirildiği, bu sebeple el-Akîde metninin Ebû Hanîfe'nin itikadî görüşlerinin tek muteber kaynağı olduğunu savunan Selefî düşünceye dayanan iddiaların, İbn Ebi'l-İzz tarafından kabul görmediğini söyleyebiliriz. Dahası, İbn Ebi'l-İzz, benimsediği Ehl-i Hadis görüşlerini yazdığı Tahâvô Akîdesi şerhine yansıtıp Tahâvî'nin cümlelerini Ehl-i Hadis görüşü paralelinde yorumlayarak onun aslında bir Selefî/Ehl-i Hadis olduğunu göstermek istemiş bunu yaparken de asıl metni zaman zaman mecrasından çıkarmıştır. Onun, Tahâvî Akîdesi üzerine yaptığı şerh çalışması ile İmam Tahâvî üzerinden Ebû 
Hanîfe ile Ehl-i Hadisi birbirine yaklaştırma gayreti içinde olduğu söylenebilir. Ebû Hanîfe'yi Tahâvî üzerinden Selefî/Ehl-i Hadis fikirlerle uzlaştırırken de, Mâturîdîleri eleştirmesi, Ebû Hanîfe ile Mâturîdîleri birbirinden ayırma isteğinin bir izharı olarak görülmelidir.

Buna göre Tahâvî Akîdesi üzerine yapılmış mezkûr iki şerhin birbirinden çok farklı olduğu ortaya çıkmıştır. Bu iki çalışma Tahâvî Akîdesi üzerinden o günün Mısır'ı için biri Semerkant Mâturîdîliği eksenli bir Hanefîlik, diğeri ise Ehl-i Hadis eksenli Hanefîlik sunma gayretinin iki farklı tezahürü olarak değerlendirilebilir.

Ebû Hanîfe' nin, Mâturîdî kelâmının kaynağı olduğu fikri, ilim dünyasında genel kabul gören bir gerçek olduğundan Bâbertî̀nin, Ebû Hanîfe'nin fikirlerini, Mâturîdîlik eksenli olarak sunmasının yadırganmayacak bir husus olduğunu düşünüyoruz. Ancak, Ebû Hanîfe'nin Selefin diğer büyük âlimleri tarafından yaygın olarak eleştirildiği düşünüldüğünde, Ehl-i Hadis eksenli bir Hanefîlik anlayışının kabulü zor bir yorum olduğunu söylememiz gerekmektedir.

O halde, İbn Ebi'l-İzz'in Ehl-i Hadis mantığına uygun bir Hanefîlik oluşturma gayretinin altında yatan sebepler neler olabilir?

Bu sebeplerden birincisi, insan psikolojisi kaynaklı olabilir. İnsan, hayatını kabul ettiği ve ödün vermek istemediği ilkeler etrafında anlamlandırarak, tutarlı bir hayat yaşamayı hedeflemektedir. Bu bakımdan İbn Ebi'l-İzz'in, amelî mezhebi olarak kabul ettiği Hanefîliğin kurucusu Ebû Hanîfe'nin itikâdî görüşlerini kendi düşünce yapısına uygun şekilde yorumladı̆̆1 ve amelî-itikâdî alan arasında bağ kurmaya çalıştığı söylenebilir.

İkinci sebep, İbn Ebi'l-İzz'in yaşadığı zamanın sosyo-kültürel yapısıdır. İçinde yaşadığı Memlük Devleti, her ne kadar farklı mezheplere saygı gösterse ve her bir mezhep için ayrı kadılar atasa da, devletin Türk devleti olduğunu ve Hanefî mezhebinin diğer mezheplere göre daha ön planda olduğunu söylememiz gerekir. Bu sebeple, Ehl-i Hadis'e dayanan fikirlerin daha geniş kesimlere yayılması Hanefîlik üzerinden yapılmaya çalışılmıştır.

Üçüncü sebep de Ebû Hanîfe'nin mezhebinin önlenemeyen yükselişi ve İbn Ebi'l-İzz'in de bundan faydalanma gayreti olabilir. Bilindiği üzere Ebû Hanîfe, Arap asabiyetinin ön planda olduğu bir dönemde ortaya attı̆̆ 1 itikâdî görüşleriyle, öncelikli olarak mevâlinin olmak üzere, Müslümanların çoğunun beğenisini kazanmıştır. Hem Müslümanın günlük hayatında karşılaşabileceği sorunlara makul ve pratik fikhî çözümler getirmesi, hem de her kesimi kucaklayıcı itikâdî görüşleri ile Ebû Hanîfe önder bir âlim 
olmuştur. Birçok İslâm beldesinden gelen talebe sayesinde Ebû Hanîfe'nin mezhebi onun hiç gitmediği uzak diyarlarda kabul görmüş, insanlar Ebû Hanîfe takipçisi oluvermişlerdir. Ebû Hanîfe'nin fikirlerinin bir temsilcisi ve Mısır Hanefîliğinin otorite ismi ise Tahâvî́dir. Bu durumda, o zamanın şartlarında Selefîlik/Ehl-i Hadis propagandasının, Tahâvî metni üzerinden yapılabileceği gerçeği ortaya çıkmaktadır. Bu sebeple İbn Ebi'l-İzz'in, Ebu Hanîfe'yi Mısır Hanefîliğinin otorite metni üzerinden Ehl-i Hadis ve Selefe ait görüşlere dayanarak okumaya çalıştı̆̆ını söyleyebiliriz.

\section{Kaynakça}

Abdulcabbar, el-Kadî Ebu'l-Hasan el-Hemedânî el-Esedebâdî (415/1025), Şerhu'l-Usûli'l-Hamse, Terc.: İlyas Çelebi, İstanbul: Türkiye Yazma Eserler Kurumu Başkanlığı Yayınları, 2013.

Ahmed b. Hanbel, Ebû Abdillâh b. Muhammed b. Hanbel eş-Şeybânî el-Mervezî. el-Müsned, Kahire: Müessesetü Kurtuba, ts. Usûlü's-Sünne, Bask1 yy, ts.

Aydınlı, Osman. Akılıı Din Söylemi, Farklı Yönleriyle Mu'tezile Ekolü, Ankara: Hititkitap Yayınları, 2010.

Aytekin, Arif. "Bâbertî". Türkiye Diyanet Vakfi İslâm Ansiklopedisi 4: 377-378 Ankara: TDV Yayınları, 1991.

Bâbertî, Ekmeluddîn Muhammed b. Muhammed el-. (786/1384), Serhu Akîdeti ehli's-sünne ve'lcemâa. Thk. Arif Aytekin, Kuveyt: Vakıflar ve İslâmî İşler Bakanlığı Yayınları, 1989.

Şerhu'l-akîdeti't-tahâviyye. Thk. Abdusselâm b. Abdilhâdî Şennâr, Beyrut: Dâru'l-Beyrûtî, 2009/1430.

Bâkıllânî, Kâdî Ebu Bekir b. et-Tayyib el-Basrî el-. (403/1013), El-İnsâfu Fîmâ Yecibu I'tikâduhu Velâ Yecûzu'l-Cehlu Bihi. Thk. Muhammed Zâhid b. el-Hasan el-Kevserî, Mektebetü'l-Ezheriyye Li't-Türâs, 2000.

Bedir, Murteza - Koca, Ferhat. "Ebu'l-Usr Pezdevî," Türkiye Diyanet Vakfı İslâm Ansiklopedisi 34: 264-266, Ankara: TDV Yayınları, 2007.

Berbehârî, Ebû Muhammed Hasan b. Ali el-. Şerhu's-Sünne. Thk: Salih b. Fûzân, Kahire: Mektebetü el-Hâdî el-Muhammedî, 2008.

Buhârî, Muhammed b. İsmail Ebu Abdullah el-Cu'fî el-. Sahîhu'l-Buhârî. Thk. Mustafa Edip, Beyrut: 1987.

Cebrîn, Abdullah b. Abdurrahman el-. Şerhu Usûli's-Sünne. Riyad: 1420.

Cüveynî, Ebul-Meâlî Abdulmelik b. Abdillâh b. Yûsuf el-. Kitâbu'l-İrşâd ilâ Kavâtii'l-Edille fì Us ûli'l-I'tikâd. Thk. Esad Temîm. Beyrut: Müessesetü'l-Kütübi'l-Sekafiyye, 1985.

Çubukçu, Asri. “Ekmelüddîn Bâbertî, Hayatı ve Eserleri”. Ekmelüddîn Bâbertî'yi Keşif Yolunda I. Ekmelüddîn Babertî Sempozyumu Bildirileri, (Erzurum, 28-30 Mayıs 2010). Ed. Selçuk Coşkun. Erzurum: Bayburt Üniversitesi Yayınları, 2014.

Ebû Davûd es-Sicistânî. es-Sünen. Beyrut: Dâru Kütübi'l-Arabî, ts. 
Ebû Hanife, Nu'man b. Sâbit. El-Fıkhu'l-Ekber, (İmam-1 A'zamın Beş Eseri) Trc. Mustafa Öz, İstanbul: Marmara Üniversitesi İlahiyat Fakültesi Vakfı Yayınları, 2016, Arapça kısmı.

El-Âlim Ve'l-Müteallim, (İmam-1 A'zamın Beş Eseri) Trc. Mustafa Öz, İstanbul: Marmara Üniversitesi İlahiyat Fakültesi Vakfı Yayınları, 2016, Arapça kısmı.

Ebu Muhammed, Abdülhak İşbilî. El-Ahkâmu'ş-Şeriyyeti'l-Kübrâ. Thk. Ebu Abdullah Hüseyin b. Akâşe, Riyâd, 2001.

Eş'arî, Ebu'l-Hasan Ali b. İsmail el-. Kitâbu'l-Lum'a Fî̀'r-Reddi Alâ Ehli'z-Zeyği Ve'l-Bid'a. Thk. Hamûde Ğarâbe, Kahire: Mektebetü'l-Hânicî, 2010.

...................., Makâlâtu'l-İslâmiyyîn ve İhtilâfu'l-Musallîn, Tah: Helmut Ritter, 3. Baskı, Wiesbaden: $1400 / 1980$

Hallâl, Ebu Bekr Ahmed b. Muhammed b. Harun b. Yezîd el-. es-Sünne. Thk. Atiyye ez-Zehrânî, Riyad: Dâru'-Râye, 1989.

İbn Ebi'l-İz, Sadruddin Ali b. Ali b. Muhammed ed-Dımeşkî el-Hanefî. Şerhu'l-akîdeti't-tahâviyye, Thk. Ebû Abdillah Mustafa İbnu'l-Adeviyye, Baskı yy, 2002/1423.

İbn Hibbân, Muhammed Ebû Hâtim et-Temîmî el-Büstî. Sahîhu İbn Hibbân, Beyrût, 1993.

İbn Mâce, Ebû Abdillâh Muhammed b. Yezîd Mâce el-Kazvînî. Sünen. Thk. Muhammed Fuad Abdulbâkî, Beyrut: Dâru'l-Fikr, ts.

İbn Mende, Ebu'l-Kasım Abdurrahmân b. Muhammed b. İshâk el-Abdî el-İsfahânî. Kitâbu'l-İman. Thk. Ali b. Muhammed b. Nâsır el-Fakîhî, Beyrut: Müessesetü'r-Risâle, 1985.

İbn Teymiyye Ebu'l-Abbâs Takıyyüddîn Ahmed b. Abdilhalîm b. Mecdiddîn Abdisselâm el-Harrânî. Kitâbu'l-Îman, Baskı yy, Dâru İbn Haldun, ts.

Kitâbu'l-Îmânu'l-Evsat, (Mecmu'u Fetâvâ içinde, 7. Ciltte). Thk. Âmir el-Cezzâr, Enver Elbâz, Dâru'l-Vefâ, 2005.

İltaş, Davut, "Tahâvî", Türkiye Diyanet Vakfi İslâm Ansiklopedisi 39: 385-388. Ankara: TDV Yayınları, 2010.

İnanır, Ahmet, “Ekmelüddin el-Bâbertî’nin en-nüketü'z zarîfetü fî Tercîhi'l-mezhebi Ebi Hanîfe" Adlı Risalesinin Tahkik ve Tercümesi". Ekmelüddîn Bâbertî́yi Keşif Yolunda I. Ekmelüddîn Babertî Sempozyumu Bildirileri, (Erzurum, 28-30 Mayıs 2010). Ed. Selçuk Coşkun. 303-346, Erzurum: Bayburt Üniversitesi Yayınları, 2014.

“İbn Ebi'l-İzz'in “İttibấ”" Adlı Risalesi Bağlamında Ebu Hanîfe ve Hanefî Mezhebi Örneğinde Taklide Dair Görüşleri", Gaziosman Paşa Üniversitesi IIlahiyat Fakültesi Dergisi 1/2 (Haziran 2013): 225-260.

Kahraman, Abdullah. “Ekmelüddîn el-Bâbertî’nın Fıkıh Usûlündeki Yeri ve Usûle Dair İki Eseri: et-Takrîr ve er-Rüdûd ve'n-Nükûd". Ekmelüddîn Bâbertî́'yi Keşif Yolunda I. Ekmelüddîn Babertî Sempozyumu Bildirileri, (Erzurum, 28-30 Mayıs 2010). Ed. Selçuk Coşkun. 239-254, Erzurum: Bayburt Üniversitesi Yayınları, 2014.

Kevserî, Muhammed Zâhid el-. Fıkhu ehli'l-lrak ve hadîsuhum. Thk. Ebu Gudde, Beyrut: 1970.

Kopraman, Kazım Yaşar. "Baybars I". Türkiye Diyanet Vakfı İslâm Ansiklopedisi 5: 221-223. Ankara: TDV Yayınları, 1992.

Karadut, Ahmet. "Ebû Ca'fer et-Tahâvî Hayatı ve Eserleri". Diyanet Dergisi 19/2, (Ankara: 1983): 53-64. 
Mâturîdî, Ebû Mansur Muhammed b. Muhammed. Kitâbu't-Tevhîd. Thk. Bekir Topaloğlu, Muhammed Ârûçî, Beyrut: Dâru Sâdır, 2010.

Te'vîlâtu Ehli's-Sünne, Tah: Mecdî Bâsellûm, 7. Cilt. Beyrut: Dâru'l-Kütübi'l-İlmiyye, 2005

Nesefî, Ebu'l-Muîn Meymûn b. Muhammed. Tabsıratu'l-edille fì usûli'd-dîn, Thk. Muhammed el-Enver Hâmid Îsâ, Kahire: Mektebetü'l-Ezheriyye li't-Türâs, 2011.

Kitâbu't-temhîd fì usuli'd-dîn. Thk. Muhammed Abdurrahman eş-Şâgûul, Kahire: el-Mektebetü'l-Ezheriyye li't-Türâs, 2006.

Bahru'l-Kelâm, Thk. Veliyyuddin Muhammed Salih Ferfur, Şam: Mektebetü Dâru'l-Ferfur, 2000.

Nesefî, Ebu'l-Berekât Hâfızüddîn Abdullah b. Ahmed b. Mahmûd en-. el-I'timâd fi'l-i'tikâd. Thk. Abdullah İsmail, Kahire: el-Mektebetü'l-Ezheriyye li't-Türâs, 2014.

Öztürk, Yunus. "Semerkand'dan Kahire'ye Hanefî Kültürün İzleri”. İslâmî Araştırmalar Dergisi, $27 / 3$ (2016): 404-413.

Pezdevî, Ebu'l-Yusr Muhammed Sadrü'l-İslâm Muhammed b. Muhammed b. el-Hüseyn b. Abdilkerîm el-. Usûlu'd-dîn. Thk. Ahmed Hicâzî es-Sigâ. Kâhire: el-Mektebetü'l-Ezheriyye li't-Türâs, 2003.

Râzî, Muhammed b. Ömer b. Hüseyin Fahreddin et-Taberistânî er-. Muhassalu Efkarı'lMütekaddimîn Ve'l-Mute'ahhirîn Mine'l-Ulema Ve'l-Hukema Ve'l-Mütekellimîn, Thk. Tâhâ Abbdurraîf Sa'd, Kahire: Mektebetü'l-Külliyâtil-Ezher, ts.

Sâbûnî, Ebû Osman İsmail b. Abdurrahman es-. Akîdetü's-Selef ve Ashâbi,'L-Hadîs. Thk. Nâsır b. Abdurrahman el-Cedî', Riyad: Dâru'l-Âsıme, 1998.

Sâbûnî, Ebû Muhammed Nûreddîn Ahmed b. Mahmûd b. Ebî Bekr es-. Kitâbu'l-Bidâye Mine'lKifâye Fî Usûli'd-Dîn, Tah: Fethullah Huleyf, İskenderiyye: Dâru'l-Ma'rife, 1969.

.., El-Kifâye Fi'l-Hidâye, Thk. Muhammed Ârûçî, İstanbul: Dâru İbn Hazm - İSAM, 2014.

Saffâr, el-Buhârî Ebû İshak İbrâhîm b. İsmâîl b. Ahmed ez-Zâhid el-Ensârî es-. Telhîsu'l-Edille Li Kavâidi'd-Tevhîd, Thk. Abdullah Muhammed Abdullah İsmail, Kahire: el-Mektebetü'lEzheriyye li't-Türâs, 2011.

Semerkandî, Ebu'l-Leys Nasr b. Muhammed b. Ahmed b. İbrâhîm es-. Tefsîru's-Semerkandî Bahru'l-Ulûm-. Thk. Ali Muhammed Muavvaz ve diğerleri, Beyrut: Dâru'l-Kütübi'l-İlmiyye, 1993

Şennâr, Abdusselâm b. Abdilhâdî eş-. Beyrut: Dâru'l-Beyrûtî, 1430/2009.

Tahâvî, Ebû Ca'fer el-Hanefî et-. el-Akîdetü't-tahâviyye -Beyânu Akîdeti Ehli's-Sünneti Ve'l-Cemaa-, Beyrut: Dâru İbn Hazm, 1416/1995.

Taşköprîzade, Ahmed b. Mustafa. Miftâhu's-Saâde ve Misbâhu's-Siyâde Fi Mevzûâti'l-Ulûm, Beyrut: Dâru'l-Kütübi'l-1̇lmiyye, 1985.

Timür, İhsan. Et-Tahâvî'nin Akîde Şerhlerinde İtikadi Farklılaşmalar, Doktora tezi, Ankara Üniversitesi, 2016.

Türcan, Galip, “el-Bâbertî́nin Kelâm’a Bakıșı -Ebû Hanîfe'nin etkisi Bağlamında Bir Değerlendirme-“. Ekmelüddîn Bâbertî̀yi Keşif Yolunda I. Ekmelüddîn Babertî Sempozyumu Bildirileri, (Erzurum, 28-30 Mayıs 2010). Ed. Selçuk Coşkun. 359-373. Erzurum: Bayburt Üniversitesi Yayınları, 2014.

Hitit Üniversitesi İlahiyat Fakültesi Dergisi, 2018/1, c. 17, sayı: 33 